\title{
Rocky shores as tractable test systems for experimental ecology
}

Stephen J. Hawkins ${ }^{1,2,3}$, Kathryn E. Pack ${ }^{1,2}$, Kieran Hyder ${ }^{4,5}$, Lisandro Benedetti-Cecchi ${ }^{6}$, Stuart R. Jenkins ${ }^{7}$

1. School of Ocean and Earth Science, National Oceanography Centre Southampton, University of Southampton, Southampton, SO14 3ZH, United Kingdom

2. Marine Biological Association of the United Kingdom, The Laboratory, Plymouth, PL1 2PB, United Kingdom

3. School of Biological and Marine Sciences, University of Plymouth, Plymouth, United Kingdom

4. Centre for Environment, Fisheries and Aquaculture Science (Cefas), Pakefiled Road, Lowestoft, Suffolk NR33 OHT, United Kingdom

5. School of Environmental Sciences, University of East Anglia, Norwich Research Park, Norwich, Norfolk NR4 7TJ, United Kingdom

6. Department of Biology, University of Pisa, Via Derna 1 I-56126 Pisa and CoNISMa, Italy

7. School of Ocean Sciences, Bangor University, Menai Bridge, United Kingdom

Corresponding author: Kathryn E. Pack, email: katpac@mba.ac.uk 


\begin{abstract}
Rocky shore ecology has been studied for a long time, starting with qualitative descriptions and becoming more quantitative and experimental over time. Some of the earliest manipulative experimental ecological studies were undertaken on rocky shores. Many, over time, have made considerable contributions to ecological theory, especially highlighting the importance of biological interactions at the community level. The suitability of rocky shores as convenient test systems for ecological experimentation is outlined. Here we consider contributions from rocky shores to the emerging concepts of supply-side ecology, the roles of competition, predation and grazing, disturbance and succession and positive interactions in structuring communities. We then address alternative stable states, relationships between biodiversity and ecosystem functioning, and bottom-up and top-down control of ecosystems. We briefly consider the feedback and synergies between ecological concepts and experimental work on rocky shores, whilst still emphasizing the traditional values of marine natural history upheld in JMBA since its first publication. The importance of rigorous experimental designs championed by Underwood and co-workers is emphasized. Recent progress taking advantage of new technologies and emerging approaches is considered. We briefly illustrate how experimental studies have shown the importance of biological interactions in modulating species and assemblage-level responses to climate change and informed conservation and management of coastal ecosystems.
\end{abstract}

Keywords: rocky shores; experimental test systems; biological interactions 


\section{INTRODUCTION}

The intertidal zone has long been an entrance and window on the ocean: people have foraged for food since pre-history (Thompson et al., 2002); pioneering studies were made by the first generations of modern naturalists (Audouin \& Edwards, 1833; Darwin, 1854); and it was the playground for the early eco-tourists of the Victorian era (Gosse, 1856; Kingsley, 1859; Hawkins et al., 2007). Early marine biologists used the seashore for collecting specimens for taxonomic, morphological, developmental, physiological and behavioural research (Hawkins et al., 2016). Here we review the contribution that experimental studies on rocky shores have made to more general ecological concepts and theory.

Formal ecological studies on rocky shores stretch back at least 200 years with Audouin \& Edwards (1833) describing zonation patterns on the rocky shores of northern France. There then followed a long period of qualitative description and classification of broad patterns of distribution of conspicuous organisms on rocky shores. How zonation patterns were shaped by tidal height and wave exposure locally and how these differed geographically, culminated in the work of (Stephenson \& Stephenson, 1949, 1972), who proposed a universal scheme of zonation. Similar work, often by their many disciples, led to descriptions of zonation patterns worldwide, sometimes using versions of their three-zone scheme (e.g. Dakin, 1953, in Australia; Morton and Miller, 1969, in New Zealand; Lewis, 1964, in the British Isles and Ireland; Morton and Morton, 1983, in Hong Kong; Morton et al., 1998, in the Azores) or developing new schemes fitting local or regional contexts (e.g. Ricketts \& Calvin, 1968, on the Pacific Coast of America; Branch \& Branch, 1981, in South Africa, updated in Branch \& Branch, 2018) - see Raffaelli and Hawkins, 1996, for review of classical descriptive zonation schemes worldwide). T. A. Stephenson was a superb artist, as were many of his later emulators, although as colour photography emerged this aided description (see plates in Lewis, 1964). Many caveats arose for such qualitative classifications, especially on the seaweed-dominated sheltered shores of the North Atlantic (see Lewis, 1964 and Lewis's chapter in Stephenson and Stephenson 1972). Subsequently, Hawkins and Hartnoll (1983a), from the basis of largely experimental studies, provided a possible explanation of the causes of the three-zone system on non-sheltered North East Atlantic shores.

Qualitative studies gave way to more quantitative descriptions of distribution patterns, with precise levelling of intertidal elevation and counts made in quadrats (Southward \& Orton, 1954), or using semi-quantitative abundance scales (Moyse \& Nelson-Smith, 1963). Colman (1933), publishing in the Journal of the Marine Biological Association of the United Kingdom (JMBA), related the limits of individual species to critical tidal levels on the shore (see also Doty, 1946; Evans, 1947). Colman's work was later revisited and statistically refuted by 
Underwood (1978). The phytosociological approach of the Zurich-Montpelier school was deployed to describe algal associations primarily in the Mediterranean Sea (above and below the water line; for examples see Boudouresque, 1971, Coppejans, 1980). Phytosociology was also used by Russell $(1972,1973)$ along with some early multivariate classification analysis to describe zonation patterns in the Irish Sea.

In parallel to descriptions, laboratory experiments were used to explore differential tolerances of species of algae (Baker, 1909, 1910) and invertebrates (Broekhuysen, 1940; Foster, 1971) from different tidal heights. Higher zoned organisms were shown to be more tolerant to desiccation and temperature than those lower on the shore. Wolcott (1973) showed convincingly for mobile animals that whilst tolerance limits broadly matched zonation position, most limpet species stayed well within their tolerance limits, except for those bordering unexploited resources high on the shore; these took risks and got caught out when conditions changed. Experiments in the laboratory and on artificial panels on rafts, as well as on the shore, explored selective larval settlement behaviour. Barnacles and spirorbids were investigated by (Knight-Jones, 1951, 1953), then taken on by Crisp and colleagues (Crisp \& Knight-Jones, 1953; Crisp \& Barnes, 1954), initially at Menai Bridge in North Wales and then further afield in Britain (e.g. Millport, Barnes, 1956) and around the world (e.g. at Beaufort, North Carolina, Rittschof, 1984), mostly on barnacles related to fouling.

The first experiments in the field probably started in North-west France before the First World War (Hariot, 1909). Fischer-Piette and Hatton examined many aspects of biological interactions from the 1920s onwards at the Dinard Laboratory of the Paris Museum, using what would be recognised now as controlled field experiments (Hatton \& Fischer-Piette, 1932; Hatton, 1938). Post-war and encouraged by Orton, such approaches were taken up by Jones (1946, 1948), Lodge (1948), Burrows \& Lodge (1951), Southward (1956) at Port Erin, Isle of Man exploring the role of limpet grazing - although visibility of such work was not helped by publication in largely parochial journals (see Southward, 1964 for summary). Connell (1961a, b) experimented on the shore at Millport in the early 1950s and subsequently took this approach back to California. Perhaps prompted by Renouf \& Rees (1932), Kitching, Ebling and colleagues and students used Lough Hyne in southwest Ireland as a model experimental system starting in the 1950s (Kitching et al., 1959; Kitching \& Ebling, 1961; Ebling et al., 1962). Some early work was also done in South Africa (Broekhuysen, 1940) and Australia (Guiler, 1954; May et al., 1970). Paine started his experimental work in the early 1960s on the Northwest Pacific Coast of the USA (Paine, 1966; Paine \& Vadas, 1969) and elsewhere (New Zealand Paine, 1971; Chile, Paine et al., 1985; summarised in Paine, 1994). Such manipulative approaches expanded rapidly from the 1970s onwards, by the first students of 
Paine (Dayton, 1971, 1975; Menge, 1976, 1983; Vadas et al., 1990, 1994) and Connell (Choat,1977; Sousa 1979a, b) and in turn their numerous subsequent students, mentees and admirers (Lubchenco, 1978, 1980, 1983; Lubchenco and Menge, 1978; Gaines, 1985) around the world. This led to significant early contributions in the southern hemisphere in Chile (Moreno \& Jaramillo, 1983; Paine et al., 1985; Castilla \& Paine, 1987; including the classic papers on excluding humans collecting seaweeds and invertebrates by Castilla and coworkers, Castilla \& Duran, 1985; Castilla \& Bustamante, 1989), New Zealand (Luckens, 1970, 1975a, 1975b) and Southern Africa (Branch 1975, 1976). Much of this work focussed on the role of biological interactions among species in shaping distributions or community structure.

Following in the footsteps of Paine and Connell, much excellent work has been done since the 1970s on both coasts of North America, by Dayton, Menge, Lubchenco, Gaines, Vadas, Bertness, and many others (for recent overviews see Dudgeon \& Petraitis, 2019; Fenberg \& Menge, 2019). This has in turn influenced work in Chile (Broitman et al., 2001; Broitman et al., 2001; Aguilera \& Navarrete, 2007, 2012; Aguilera et al., 2013, 2019a) and Argentina (Bertness et al., 2006; Silliman et al., 2011; Palomo et al., 2019).

Underwood established a strong experimental ecology school in Sydney, Australia from the 1970s (e.g., Underwood, 1976, 1978, 1980, 1984, 1998; Underwood \& Jernakoff, 1981,1984; Underwood et al., 1983) with world-wide influence. He emphasized the importance of hypotheses tested using well-designed experiments and rigorous statistical analyses - any experiments done should be done properly (Underwood, 1981, 1985, 1986, 1988, 1991a, 1992a). His approach was enthusiastically embraced by his numerous students (earlier ones including Creese \& Underwood, 1982; Chapman, 1986; Fairweather, 1988; Chapman \& Underwood, 1992a), post-docs, visiting fellows, and a like-minded international network (e.g., Benedetti-Cecchi, A.R.O. Chapman, Coleman, Aberg, Pavia, Petraitis, Vadas).

Thus experimental studies on rocky shores had become mainstream from the 1980s - with several subsequent generations of students and post-docs world-wide (see reviews in John et al., 1992; Bertness et al., 2001, 2014; Hawkins et al., 2019a, b, c). In New Zealand, Choat brought back insights from his time with Connell in California (Choat, 1977) and was an early champion of experimental approaches. Subsequently, Schiel has combined insight into the natural history of systems with rigorous experimental approaches (Schiel et al., 2019a). In South Africa, Branch, McQuaid and students built on the classical work by the Stephensons to better understand, through experimentation, underlying processes (McQuaid \& Blamey, 2019). Experimental approaches have also prospered in Hong Kong and beyond in greater China (Williams et al., 2019). 
The viewpoint of intertidal experimental ecology presented here started in the Isle of Man in the mid-1970s when the lead author (SJH) was prompted by Hartnoll to revisit the experimental work done by Jones, Lodge, Burrows, Southward in the late 1940s and 1950s. At the time key influences were the emerging experimental work by Paine, Connell, Menge, and Lubchenco as well as the work by Southward at the Marine Biological Association (on long-term climate fluctuations and recruitment, Southward 1963, 1967; recovery from oil-spills, Southward \& Southward, 1978; plus Lewis, 1964, and colleagues at Robin Hoods Bay on the role of recruitment processes on rocky shores and environmental monitoring, Lewis, 1976; Lewis \& Bowman, 1975; Bowman \& Lewis, 1977). Another influence was Norton at Glasgow, a former student of Burrows, who had also commenced experimental work on fucoid distributions on the shore at Millport (e.g., Schonbeck \& Norton, 1978, 1980a). SJH with subsequent students, many of whom have become colleagues (including two co-authors on this paper) continued the tradition at Port Erin, on the Isle of Man with further experiments (e.g., Jenkins et al., 1999a, b, c, 2005; Thompson et al., 2004 jointly working with Hartnoll and Norton), extending into spatial statistics (Johnson et al., 1997) and modelling (Burrows \& Hawkins, 1998; Hyder et al., 1998;Johnson et al., 1998a, b, c). This has been aided by a wider network of colleagues in Europe (including an Italian co-author first met at a conference in Liverpool on plant-animal interactions in 1990), all interested in experimental ecology, and able to work together within European-funded projects and networks. This network of collaborators has been profoundly influenced by the Underwoodian approach to experimental ecology, promulgated by numerous training workshops by Underwood and Chapman and their advisory work on European projects such as EUROROCK

Underwood et al. (2000) succinctly define and discuss different approaches to describing pattern in ecology, advocating the importance of logical and structured quantitative observations or surveys testing hypotheses about pattern, so-called mensurative experiments, as the essential basis upon which experimental studies of process can proceed. Such studies have advanced understanding of rocky shore ecology, and are often a stand-alone precursor (Menconi et al., 1999; Benedetti-Cecchi et al., 2000a; Jenkins et al., 2000; Johnson et al., 2003; Martins et al., 2007; 2008) or acomponent of wider manipulative studies (Sousa, 1979a; Thompson et al., 2004) generating hypotheses or informing modelling approaches (Hyder et al., 1998, 2001; Svensson et al., 2005). We have not, however, extensively considered them here, other than in the context of supply-side ecology where experimental manipulations are less feasible. 
Here we focus on the use of rocky seashores as a convenient tractable system for manipulative field experiments on processes that have contributed to ecological concepts and theory. Firstly, we outline the reasons why the shore is so amenable to descriptive and experimental research. Next, we summarise the contributions that manipulative experimental intertidal ecological studies have made to general ecological theory at population, community, and ecosystem levels. We then discuss the intertwining of theory and experiment, the importance of advances in methodology in developing the field and the new opportunities arising from such new technologies and approaches. We conclude by considering how experimental approaches have helped understand the role of biological interactions in responses of marine life to anthropogenic climate change as well informing environmentally sensitive adaptation by society to climate-driven rising seas in the context of widespread coastal urbanisation. We stress this is a selective and personal view of the topic - not an exhaustive review. We focus mainly on the seashore but occasionally stray into the shallow sub-tidal zone, especially in the virtually tide-less Mediterranean. Furthermore, we have highlighted work done in Britain and Ireland plus neighbouring northeast Atlantic and Mediterranean countries - the traditional hinterland of JMBA. This work has led to the shores of the northeast Atlantic being some of the most studied in the world (Hawkins et al., 2019b), with much recent progress in the Mediterranean (Benedetti-Cecchi et al., 2019).

\section{THE SEASHORE AS A TRACTABLE SYSTEM}

Paine (1966, 1969, 1971, 1974) and Connell (1961a, b, 1972) as pioneers of experimental ecology have espoused the values of manipulative field experiments (Connell, 1974; Paine, 1994 ) and the appropriateness of the seashore as a test system (see also Menge \& Branch, 2001). As Connell (1974) neatly summarised: in a laboratory experiment all conditions are held constant other than those being tested; in contrast in a field experiment all the variables are allowed to vary, presumably the same way in adjacent similar treatment and control plots, other than those being manipulated (often one or two, rarely more at the time of his writing, but more complex designs are now more commonplace). The seashore has a sharp vertical environmental stress gradient from low water to beyond the influence of sea spray. This gradient is largely unidirectional, increasing up shore for the majority of organisms on rocky shores that have marine evolutionary affinities. For the few organisms of terrestrial origins, the stress gradient is reversed (Raffaelli \& Hawkins, 1996). The environmental extremes encountered over the short, sharp intertidal gradient are experienced over much larger distances in other systems. For example, moving a few metres up a rocky shore from low water can be the equivalent of ascending a 3000 metre mountain in terrestrial systems. There is a horizontal wave action or exposure gradient between sheltered bays and exposed 
headlands. This is not unidirectional and many species have optima at intermediate points between the two extremes (Raffaelli \& Hawkins, 1996). These sharp gradients are locally modified by the topography of the shore with rockpools, cracks and crevices plus shaded and unshaded areas reflecting geomorphologically-generated habitat complexity (Johnson et al., 2003). This variety of environmental conditions in close proximity has made transplant experiments (with appropriate controls), a powerful tool in understanding the direct and indirect influences of the environment on the distribution, abundance, growth, and survival of species (e.g., Schonbeck \& Norton, 1978, 1980a). The modulation of the intensity of biological interactions by the physical environment can also be explored along these sharp local gradients (Bertness \& Leonard, 1997), and amongst local mosaics of micro-habitats (Johnson et al., 1998b, 2005).

The nature of rocky intertidal organisms also makes them amenable to manipulation. Most intertidal organisms are reasonably sized with the biggest algae being at most $2-3$ metres in length. Few animals are bigger than 30 centimetres and most are less than 10 centimetres. Most of the suspension feeders are sessile, and many of the grazers and predators are reasonably slow-moving and sedentary enabling removal and exclusion experiments. Work over the last 20 years, however, has emphasized the importance of mobile predators such as foraging by crabs (Silva et al., 2008, 2010, 2014; Christofoletti et al., 2011) and fish (Taylor \& Schiel, 2010) when the tide is in, and birds when the tide is out (Hockey \& Underhill, 1984; Coleman et al., 1999; Coleman \& Hockey, 2008) or by diving (e.g. eider ducks, Hamilton et al., 1999). Few of the algae and animals live more than a decade or so - although there are exceptions such as Ascophyllum nodosum where genetic individuals may live well over 100 years, even if individual fronds are rarely older than 10 (Åberg, 1992). The relatively low cost and easy access to rocky shores also greatly facilitates the manipulation of these organisms for experiments.

Most conspicuous sessile animals and algae compete for a clearly definable and measurable resource - two-dimensional space to live on the rocks - providing access to light for plants and particulate food for suspension-feeders. The flora and fauna growing on rocky shores can also be partitioned into layers (canopy, understorey turf, encrustations) enabling nondestructive quantification of abundance and elucidation of interaction. There are none of the invisible and complex below ground interactions that occur in soils and sediments - although bio-erosion by burrowing endolithic cyanobacteria and invertebrates such as sea urchins and molluscs, particularly burrowing piddocks (Pinn et al., 2008) can modify softer rock habitats, creating complexity. These attributes make the flora and fauna easy to quantify and manipulate, and to measure response variables primarily non-destructively. Short life-spans 
and rapid growth mean that clearance or removal experiments of dominant canopy-forming or rock covering species can occur within 3-5 years - the duration of most PhDs (but see note of caution from Jenkins \& Uyà (2016) and a plea for longer duration of manipulative marine studies). Some species do take longer, with maybe 20 or more years for the recovery of $A$. nodosum following canopy removal (Jenkins et al., 2004; Ingólfsson \& Hawkins, 2008). Recovery times are, however, generally much swifter than in terrestrial systems where, for example, removal of trees may take hundreds of years to recover. When recovery does not occur, it can point to interesting explanations such as alternative stable states (BenedettiCecchi et al., 2015; Petraitis \& Dudgeon, 2015; Menge et al., 2017).

The hard nature of rocks enables various devices such as exclusion fences or cages, settlement plates or tiles, or transplanted rocks to be attached via screws or quick-set cement or epoxy glues. Once technological constraints were overcome (e.g. early use of generators and electric-drills Dayton 1970, or compressed air drills, Hawkins \& Hartnoll, 1979), the experimental approach proliferated, particularly since the introduction of petrol-driven and cordless drills and better fast-setting underwater epoxies. Thus, grazers and predators have been excluded or enclosed at varying densities, algal canopies and understorey turfs and encrusting invertebrates removed, thinned or transplanted, and the responses of individual species or whole assemblages measured.

In most regions of the world, the taxonomy of the common and important species is well understood. Cryptic speciation can, however, cause problems (e.g. in the North Atlantic and Mediterranean: Chthamalus stellatus, into C. stellatus and Chthamalus montagui by Southward, 1976; Fucus spiralis into F. spiralis and Fucus guiryi by Zardi et al., 2011). Recent developments in molecular-based genetics and taxonomy have accelerated the detection of cryptic species (Chan et al., 2007, 2012). However, whilst taxonomic accuracy is essential at the population level, it is not critical for many community and ecosystem level studies. For example many community-level studies such as those making comparisons amongst biogeographic regions, usefully lump algae and sessile animal species into functional categories (canopies, turfs, encrustations, barnacles) or more nuanced functional groups (e.g. for algae Steneck \& Dethier, 1994).

\section{CONTRIBUTIONS TO GENERAL ECOLOGY THEORY}

All of the above attributes have earned rocky shores the label as the fruit fly of ecology (Berlow, 1997). Below we consider how experimental research on rocky shores has contributed to general ecological theory at the population and especially the community level. Studies on 
rocky shores have made a major contribution to emphasizing how recruitment drives populations and the consequences for communities - what has become known as supply-side ecology (Lewin, 1986). Ground-breaking experiments on the roles of biological interactions in determining distributions and shaping communities through competition, grazing and predation, disturbance and succession, plus positive interactions are then outlined before turning to alternative stable states, the relationship between biodiversity and ecosystem functioning, and the relative importance of bottom-up forcing and top-down control in ecosystems.

\section{Supply-side ecology}

The mechanisms governing the distribution and abundance of populations of marine benthic invertebrates have been much debated. The majority of invertebrates living on rocky shores exhibit a complex life cycle with a pelagic larval phase. Hence local reproduction and input of new individuals to a particular site is often decoupled leading to extensive debate regarding the importance of processes that determine input of individuals (larval transport, supply and settlement) versus processes occurring after arrival (competition, predation, disturbance, facilitation following settlement) in determining patterns of adult distribution. Much early research on rocky shores focused on the dominant role of post-settlement processes in determining observed patterns (Connell, 1961a, b; Paine, 1966; Dayton, 1971; Menge \& Sutherland, 1976). For example, Connell's classic work on competition in Millport Scotland showed clearly that the distribution of Chthamalus spp. on the shore was determined not by the pattern of settlement but by strong interspecific competition with Semibalanus balanoides. Connell (1961b) was very aware of the existence of failure years when $S$. balanoides recruitment did not occur, indicating a role for pre-settlement processes. The importance of larval supply and settlement in determining adult distribution can be represented by the recruitment limitation hypothesis (sensu Doherty, 1981) which states that when larval supply is insufficient for the total population size to reach a carrying capacity, increases in recruitment will lead to increases in adult population size (Connell, 1985; Menge, 1991).

The supply and settlement of both invertebrate larvae (Hawkins \& Hartnoll, 1982a; Gaines \& Roughgarden, 1985; Roughgarden et al., 1988; Hunt \& Scheibling, 1996; Jenkins et al., 2000; O'Riordan \& Murphy, 2000; McQuaid \& Lawrie, 2005) and algal propagules (Reed \& Foster, 1984; Åberg \& Pavia, 1997) varies greatly in both space and time. Observational studies that identify the scales at which variation occurs have given important insight into the mechanisms determining the distribution of larvae and ultimately supply to the shore (Gaines \& Roughgarden, 1985). Small-scale local variation tends to be ubiquitous (Fraschetti et al., 2005), reflecting interactions occurring at or soon after settlement although larger scale 
variability is common indicating the importance of patterns in the regional larval pool (Barnes, 1956) and regional physical transport processes (Hughes et al., 1999). Decades of research have demonstrated clearly that understanding of processes such as upwelling (Roughgarden et al., 1988), tidal and wind-driven currents (Hawkins and Hartnoll, 1982; Bertness et al., 1996; McQuaid \& Phillips, 2000), internal waves (Shanks, 1983), surf zone barriers (Rilov et al., 2008) and wave action (Pfaff et al., 2011), and the way these processes interact with local and regional coastal topography (Archambault \& Bourget, 1996) is required to provide predictive understanding of supply to the rocky shore. Work of Roughgarden and colleagues on the central Californian coast showed convincingly that inter-annual variability in upwelling determines patterns of recruitment across large areas (Roughgarden et al., 1988; Farrell et al., 1991); while further north on the coast of Washington, barnacle recruitment rates are influenced by shoreward transport of offshore plankton, in surface slicks, generated by tidally forced internal waves (Shanks, 1983, 1986; Shanks \& Wright, 1986).

While physical transport processes determine the rate and timing of arrival of larvae and propagules to the shore, consideration of behaviour is paramount in determining settlement patterns (Jenkins, 2005). Some population or community models assume that settlement is a function of larval supply and the amount of free space available (Gaines et al., 1985; Roughgarden et al., 1985; Hyder et al., 2001). However, reality may be far more complex. For example, Minchinton (1997) demonstrated that recruitment of the tubeworm Galeolaria caespitosa into patches of free space was related not to patch area but to patch perimeter suggesting an important role for gregarious settlement close to conspecifics. The work of Crisp and co-workers in Menai Bridge, Wales throughout the 1950s and 1960s was critical in demonstrating the complex patterns of behaviour and finely-tuned discriminatory abilities of invertebrate larvae in response to biological and physical cues to ensure that settlement occurs in a habitat that is conducive to survival, growth and, ultimately, reproduction. For example, the microbiofilm coating the rocky shore is the point of first attachment for settling larvae and propagules. Such films have been shown to promote settlement in a range of invertebrate larvae (Todd \& Keough, 1994; Qian et al., 2007), with settlers responding to cues such as age of the film, specific taxa such as diatoms, and film characteristics related to tidal height (Strathmann et al., 1981). Laboratory analyses of behaviour have demonstrated the discriminatory abilities of invertebrate larvae to a range of cues, but perhaps field tests of how larvae respond to multiple cues are more relevant. Thompson et al. (1998) showed that settling barnacle cyprids could discriminate among different microbial films in the laboratory environment, but this was irrelevant under field conditions where the presence of conspecific cues overruled cues from microbiota. Grosberg (1981) demonstrated that the larvae of species that are vulnerable to overgrowth by competitors avoid settling in the presence of a dominant 
space occupant, the colonial tunicate Botryllus schlosseri, whereas no avoidance was displayed by species that are not vulnerable. However, a contrasting response was recorded by Bullard et al. (2004), who failed to detect any avoidance of competitors during larval settlement.

The relevance of spatial and temporal variation in larval supply to adult populations is ultimately dictated by the fate of settlers. No matter how variable the supply of larvae to the shore, if the post-settlement process is density-dependent then the variability will be dampened out (Holm, 1990; Jenkins et al., 2008a). New arrivals to the rocky shore are subject to radically different environmental conditions than those experienced in the pelagic larval environment, and early post-settlement mortality is high. For example, Gosselin \& Qian (1997) reported levels of over $90 \%$ mortality during the juvenile period in 20 out of 30 studies reviewed on invertebrates. The same is true for algae; for example, Wright et al. (2004) showed that only 2 of 5,395 embryos of Fucus gardneri survived to become visible recruits. Sources of mortality include desiccation and disturbance, both physical (Vadas et al., 1990) and biological (Jenkins et al., 1999a).

The integration of levels of larval supply, patterns of settlement and post settlement mortality dictate the abundance and distribution of adults on rocky shores. Following much debate, based on work on rocky shores and by extensive work on coral reef fish (Doherty \& Williams, 1988; Shima, 2001; Wilson \& Osenberg, 2002), a general consensus was reached whereby populations may be limited by arrival of new individuals when supply and settlement is relatively low, but at high recruitment sites variability in supply and settlement has little impact on adult abundance owing to strong density dependent post-settlement processes. This recruit-adult hypothesis (sensu Menge, 2000a) states that the relative importance of recruitment declines with increasing density of recruits (Connell, 1985; Roughgarden et al., 1985; Sutherland, 1990; Menge, 2000b). Manipulative experimental work in North Wales on the intertidal barnacle $S$. balanoides which shows meso-scale variation in density and recruitment around Anglesey (Bennell, 1981; Hyder et al., 1998), partially supports this view, but also shows that recruitment can be a useful predictor of adult density across all recruit densities, from very low to very high (Jenkins et al., 2008a). Here the relationship between recruitment and adult density switched from positive, at low levels, to negative at high levels (Figure 1) owing to strong over-compensatory density-dependent mortality. Such considerations are clearly relevant to understand how populations are regulated. However, the supply of individuals across a range of taxa can also be used in predictive manner to consider the structuring forces in whole communities. Consistent large-scale differences in recruitment intensity observed along the Pacific coast of North America (Connolly et al., 2001) 
can lead to differences in the strength of interspecific interactions. Experimental determination of community organisation in Oregon and Washington where recruitment is high has emphasised the role of competition and predation. In contrast, in California, where upwellinginduced larval loss from the coastline is high, the influence of settlement variation has been stressed (Connolly \& Roughgarden, 1998).

Fig. 1. The relationship between the density of manipulated recruits of $S$. balanoides in June 2002 on shores of North Wales and the density of surviving adults 2 years later. On both shores, adult density is positively related with recruitment at low densities, switching to no relationship at moderate densities and a negative relationship when recruitment is very high. From Jenkins et al., 2008a.

The interplay of ecological theory, data collection, and modelling generated many excellent examples of early interdisciplinary research. Here, collaborations between ecologists and modellers led to significant advances in understanding of ecology, where cyclic interactions between experimental work and modelling occurred. Data were generated to understand processes that were then used to parameterise models; models highlighted data gaps and generated hypotheses for further experiments, which in turn improved models.

Mechanistic models of barnacles have successfully linked small-scale dynamics of adult benthic populations to large-scale hydrodynamic models of the larval stage (Roughgarden et al., 1985; Roughgarden et al., 1987; Possingham \& Roughgarden, 1990; Roughgarden et al., 1991; Shkedy \& Roughgarden, 1997; Connolly \& Roughgarden, 1998). Thus, a demographic theory for an open population with space-limited recruitment has been proposed and tested using data for the barnacle Balanus glandula in California (Gaines et al., 1985; Gaines \& Roughgarden, 1985; Roughgarden et al., 1985). The model predicted cyclic fluctuations in free space at high settlement rates, but could not explain the 30 week period of these cycles (Roughgarden et al., 1985), which lead to further experimental and modelling to develop understanding of the system. Later models showed that at critical density of barnacles the areas are subject to density-dependent predation by starfish, but at low density the threshold for predation is not reached and free space is always present (Possingham et al., 1994). Coupled models of oceanic processes of the larval stage and adult benthic stage were developed (Possingham \& Roughgarden, 1990; Roughgarden et al., 1991). Farrell et al. (1991) showed that the supply of larvae was inversely proportional to the strength of upwelling and that larvae were passively transported offshore to the oceanic front. This gave rise to models where the larvae were produced and passively transported to the frontal boundary. 
The collapse of upwelling leads to areas of the front colliding with the shore and giving peaks of recruitment (Roughgarden et al., 1991). The predictions from models coupling large-scale oceanic processes that affect the larvae with small-scale benthic dynamics have led to development of a community model for California and Oregon (Connolly \& Roughgarden, 1998).

Modelling has also been used to examine the factors structuring barnacle populations across Europe (Hyder et al., 1998; 2001; Svensson et al., 2005). For example, Hyder et al. (2001) applied open models with space-limited recruitment to large scale observations of Chthamalus montagui and other barnacles across Europe (Jenkins et al., 2001; O'Riordan et al., 2004). Modelling demonstrated differences between the processes structuring barnacle populations in the Atlantic and Mediterranean (Hyder et al., 2001). The models showed the amount of free space varied within a year, but the pattern differed between sites in the Atlantic and Mediterranean (Hyder et al., 2001). Modelled free space represented the balance between space-filling and space-creating processes, which may reflect differences in the timing of processes in the Atlantic (mortality due to storms and low growth in winter) and Mediterranean (mortality due to desiccation and low growth in summer) (Hyder et al., 2001). Genetic differentiation has been found between Mediterranean and Atlantic C. montagui (Dando \& Southward 1980; Pannacciulli et al. 1997), which could be driven by neutral processes resulting from hydrographic separation and/or variation in timing of selective pressures. This combination of modelling and experimental/empirical work has led to major advances in understanding of the processes driving open populations for which barnacles have proved an excellent test system.

\section{COMPETITION AND DISTRIBUTIONS ALONG ENVIRONMENTAL GRADIENTS}

Connell's (1961a) classical experiment on competition between fast-growing mid and low shore Semibalanus balanoides and slower-growing high shore Chthamalus montagui at Millport showed the importance of biological interactions along environmental gradients in setting lower limits of zonation of individual species (for similar work in New Zealand see Luckens, 1970,1975a, b). This idea was reinforced through observations of predation setting lower limits (Connell, 1961b, 1970; Paine, 1971, 1974; Paine et al., 1985). In contrast laboratory simulations, early transplant/environment modification experiments (Luckens, 1970) and field observations of mortality at upper limits, led to Connell (1972) proposing that the upper limits of zonation of species were generally set by the direct effects of physical factors. His conceptual leap forward on understanding zonation patterns of species along environmental gradients was to suggest that the proximate causes of upper and lower limits 
had to be treated separately. Subsequent experimental removal and transplant studies, backed by realistic laboratory tolerance experiments on fucoid zonation on sheltered shores on both sides of the Atlantic confirmed the role of physical factors setting upper limits (Schonbeck \& Norton, 1978,1979a, b, c, 1980b) and biological interactions, particularly competition in setting lower limits (Lubchenco, 1980; Schonbeck \& Norton, 1980a). Some exceptions have since emerged to Connell's synthesis. Low on the shore, upper limits were shown to be set by grazing on more wave exposed shores (e.g., Southward \& Southward, 1978; Underwood, 1980; Underwood \& Jernakoff, 1981; Boaventura et al., 2002a). On sheltered shores, competition was shown to set the upper limits of some low and mid-shore fucoids, as well as lower limits (Hawkins \& Hartnoll, 1985). Ascophyllum in particular was shown in removal experiments to exclude both higher shore Fucus vesiculosus and lower shore Fucus serratus from midshore plots (Jenkins et al., 1999b, c, 2004); this competitive ability is because it can grow large via vegetative proliferation and its longevity rather than fast early growth (Johnson et al., 1998c). Ultimately the physical stress gradient from low shore to high shore determines survival, growth and hence competitive performance of algae and sessile invertebrate species. Proximately upper limits, especially for higher shore species, are set by physical factors and although generally lower limits are set biological interactions, upper limits of mid and low shore species can be also set by biological interactions such as competition and grazing. There is no convincing evidence that lower limits of essentially marine organisms are set directly by too much emersion - in Pelvetia canaliculata, which rots when transplanted lower down the shore (Schonbeck \& Norton, 1980a; Rugg \& Norton, 1987), a pathogen has been shown to cause mortality at lower tidal levels.

Much valuable work has been done on competition amongst mobile animals, particularly grazing gastropods. Experimental designs that segregate intra from interspecific competition are crucial when understanding interactions between species; such designs were pioneered by Underwood (e.g., 1978, 1984, 1986, 1988, 1992a) working with his students (e.g., Creese and Underwood, 1982; Fletcher and Creese, 1985). Intraspecific competition as expected is often more intense than interspecific competition (Creese and Underwood, 1982; Ortega, 1985; Boaventura et al, 2002b), enabling competitively inferior species to persist, especially if they, like Siphonaria, have access to a resource untapped by the superior competitor such as algae growing on Cellana shells (Creese and Underwood, 1982; see comments in Underwood, 1992). Inter-age class interactions within a species can also be important, with larger animals impacting smaller size classes (e.g. Boaventura et al., 2003), probably through competition for both food and space. The converse has also been found, with faster growing smaller animals outcompeting larger limpets (Marshall and Keough, 1994). Recently the potential role of competitive interactions among gastropods in limiting range expansion and 
hence determining range limits has been examined using scurrinid limpets in the southeast Pacific as a model system. Aguilera et al., (2019b) showed novel evidence of asymmetric competition between two congeners potentially limiting range expansion by Scurria viridula.

Whilst competition is clearly important there are emerging context-dependent caveats. Firstly resources, whether space or food, need to be in short supply. This can depend very much on local and mesoscale differences in larval or propagule supply discussed above. Competitive outcomes can also be modified by both fluctuating environmental conditions and recruitment - very common in intertidal systems - leading to co-existence of species due to absence of the equilibrium conditions theoretically needed for competitive exclusion. For instance, Connell (1961a) was able to demonstrate intense competition between barnacle species because space is highly saturated due to larval retention by fronts in the Firth of Clyde. Such retention leads to very high local recruitment compared for example to more dispersive coastal environments such as the Isle of Man (Hawkins \& Hartnoll, 1982a). Work elsewhere can lead to different outcomes (e.g., Gordon \& Knights, 2018), especially where space is undersaturated due to mesoscale recruitment differences (Jenkins et al., 2001; Burrows et al., 2010), or to low recruitment including failure years (Svensson et al., 2005). Further south in the geographic range of Semibalanus in south-west England, early juvenile mortality of the dominant Semibalanus in warm years probably releases slower growing chthamalids from competition (Poloczanska et al., 2008). Even where space is apparently undersaturated, gregarious settlement behaviour can lead to intra-specific competition (e.g., Gordon \& Knights, 2018), whilst maximizing survival and mating opportunities (Kent et al., 2003).

\section{PREDATION AND GRAZING}

Pioneering work by Paine (1966), in which the large predator Pisaster ochraceus was experimentally removed from a mussel-dominated (Mytilus californianus) shore in Washington State, led to the keystone predator concept. Paine showed that diversity of conspicuous fauna declined in the absence of this large predator. In addition, continuation of this removal experiment for several years showed that predation could also set the lower limit of mussels (Paine, 1974). Paine went on to repeat this experiment in New Zealand (Paine, 1971) and Chile (Paine et al., 1985), showing that in biogeographic settings where large starfish were prevalent (Stichaster australis in New Zealand and Heliaster helianthus in Chile) and mussels were the dominant space occupier, that a major "keystone" predator could have a disproportionate effect on the diversity and distribution of species (Paine, 1969). 
Ahead of these experiments, removals of patellid limpets in large squares or strips by Jones $(1946,1948)$ on the Isle of Man showed that the control of fucoid algal vegetation on moderately exposed rocky shores was by limpet grazing, not by wave action as previously assumed (see also Conway, 1946, for work in the Firth of Clyde). Although some of the work was published in Nature, the remainder of the more detailed follow-up work on the Isle of Man was largely published in local journals (Jones, 1948; Lodge, 1948; Burrows \& Lodge, 1950; Southward, 1956). Southward (1964) summarised this work in a chapter for a conference organised by the British Ecological Society. The importance of limpet grazing was starkly confirmed by the toxic effects of first-generation dispersants used to clean up the Torrey Canyon oil spill in 1967 (Nelson-Smith, 1968; Smith, 1968). This was one of the first spills from the newer generation of super-tankers that ran onto reefs off the west Cornish coast. Vast amounts of "detergents" a euphemism for a mix of surfactant, organic solvent and stabilizer were applied to the crude oil that came ashore. A total of 10,000 tons of dispersant were applied to approximately 14,000 tons of oil that came ashore in Cornwall (Smith, 1968). This led to vast kills of limpets and other grazers leading to an immediate bloom of green algae, followed by fucoids, which even occurred on some of the most exposed shores in Cornwall such as outside Sennen Cove (Southward \& Southward, 1978). Recovery of these treated shores took between 10 - 15 years (Southward \& Southward, 1978; Hawkins and Southward, 1992; Hawkins et al., 1983, 2017a, b). Those observations confirmed that grazing, rather than physical factors, controlled algal vegetation and that limpets can be considered a keystone grazer on the rocky shores of the northeast Atlantic (Hawkins and Hartnoll, 1983a).

Starting with removing limpets from strips or patches (Hawkins, 1981a), a more nuanced approach using limpet exclusion fences (Hawkins, 1981b) was then adopted by the next generation of researchers on the Isle of Man (reviewed in Hawkins \& Hartnoll (1983a). This teased out the interactions between limpets, barnacles, and fucoids (Hawkins \& Hartnoll, 1982b, 1983b; Hawkins, 1983), and the role of recruitment fluctuations (Hawkins \& Hartnoll, 1982a) in generating patchiness on exposed shores (Hawkins \& Hartnoll, 1983a; Hartnoll \& Hawkins, 1985). Some of this work was correctly criticised for lack of replication (Chapman, 1995). Subsequent studies used extensive replication over replicated patches, seasons, and shores and on large geographic scales (Arrontes et al., 2004; Jenkins et al., 2005; Coleman et al., 2006) confirmed the importance of limpet grazing in controlling algal vegetation, especially fucoids, in more northerly latitudes. Further north in Europe (i.e., the Isle of Man) the response to limpet removal was highly deterministic, but even in Southern Britain a greater stochastic element was apparent (Jenkins et al., 2005). Follow up work comparing the factors determining fucoid recruitment in Portugal versus the British Isles showed interactions between reproductive output, propagule supply, physical factors particularly desiccation and 
grazing influenced fucoid recruitment (Ferreira et al., 2015). In the south of Portugal, fucoid cover and biomass is reduced, propagule supply is less and physical factors reduce early growth and recruitment; whereas in the north, in less stressful conditions with ample propagule supply, grazing has a prominent regulatory role (Ferreira et al., 2014).

Spatial mapping of mosaics using geo-statistical tools (Johnson et al., 1997), probabilistic individual-based modelling (Johnson et al., 1998a) and approaches using cellular automata (Burrows \& Hawkins, 1998) have built on the underlying experiments (summarised above and in Hawkins et al., 1992) enabling simulation of the processes involved generating patchy mosaics on moderately exposed rocky shores. Jonsson et al. (2006), using a combination of experiments and modelling on artificial breakwaters, showed conclusively that limpets prevent establishment of fucoids, but wave action determines their persistence once established.

The keystone concept has received some criticism (Mills et al., 1993; Power et al., 1996). It is clearly context-dependent: appropriate large-bodied predatory and grazing species have to be present to be able to perform this role (i.e., large starfish in the Indo-Pacific; large limpets in the northeast Atlantic) and there have to be dominant space occupiers such as mussels or fucoid canopy-forming algae that are controlled by an important consumer (Power et al., 1996).

\section{DISTURBANCE AND SUCCESSION}

Rocky shores are naturally disturbed environments. The direct action of waves and indirect action through scouring as a consequence of movements of sand, gravel, and turning over cobbles and boulders (Shanks \& Wright, 1986) remove biota thereby starting secondary succession (Connell \& Slatyer, 1977). Primary succession can also be initiated by chunks of rock becoming cleaved away or the placement of new blocks on artificial shores (Hawkins et al., 1983; Moschella et al., 2005) creating virgin surfaces. In addition to physical processes, biological disturbance can arise from grazing, predation, sweeping or whiplash by canopy algae such as kelps or fucoids (Velimirov \& Griffiths 1979; Hawkins, 1983), and even intense intraspecific competition leading to hummocking of barnacles (Barnes \& Powell, 1950). All these biological processes can lead to space being made available for secondary or even tertiary succession (on top of existing biota). This is particularly the case when grazing is relaxed, leading to algal colonization (Hawkins, 1981b). Grazing pressure can keep an invisible lawn of biofilm on apparently bare rock and on barnacles (Hill \& Hawkins, 1991). 
It is, therefore, not surprising that empirical studies of disturbance and succession have been made on rocky shores, and this work has led to conceptual advances (Connell \& Slatyer, 1977; Sousa, 1979a, b, 1984a, b). Connell \& Slatyer (1977) proposed three models of succession: classical facilitation where early stages are essential for progression to later arriving species; inhibition where early or mid-successional species delayed progression to later arriving species; and the tolerance model (which nowadays would be termed a neutral model) where there are no positive or negative interactions, but species eventually came to predominate because of life history characteristics such as longevity.

In the literature, there are many examples of facilitation and inhibition (Menge, 1995), although less for the tolerance model (but see Farrell, 1991). Facilitation can be particularly important during primary succession (Wahl, 1989), when microbial films condition the surface. There is, however, some evidence of inhibition even in microbial films (Wieczorek et al., 1995). Inhibition commonly occurs when early colonizing macro-algae such as ephemeral greens and browns come to dominate rocks. Sousa (1979a) determined the importance of grazing in breaking dominance by intermediate stages hereby breaking inhibition to allow succession to proceed. The paucity of evidence for the tolerance model may simply be because studies have not been run for long-enough (Jenkins \& Uyà, 2016, for consideration of the temporal scale of manipulative experiments). In long-term experiments on Ascophyllum-dominated sheltered shores of the northeast Atlantic examples of the tolerance model may be found. Clearance areas were initially dominated by Fucus serratus and F. vesiculosus. However, slow recolonization over 10-20 years by $A$. nodosum through its ability to proliferate vegetatively in long-lived clumps and grow up through an overlying canopy of shorter-lived competitors led toward its return to dominance (Jenkins et al., 1999b, 2004; Ingolfsson \& Hawkins, 2008). These models are more classifications than a predictive framework, with Hawkins \& Hartnoll (1983b) observing that some successional sequences can involve more than one model.

Benedetti-Cecchi (2000a) revisited the successional models of Connell \& Slatyer (1977). He used a combination of traits from knowledge of natural history and outcomes of past experiments on the importance of positive and negative interactions to turn Connell \& Slatyer (1977) models of succession into predictive, but still qualitative models of succession (Figure 2). This study shows how positive indirect interactions may facilitate the establishment of species that characterise early successional stages later in succession, challenging the idea of succession as a directional sequence of species replacements. 
Fig. 2. Network of species interactions shaping rocky shores assemblages at late stages of succession on a Mediterranean rocky shore. Strong competition for space between late successional species (fleshy algae and barnacles) and limpets reduces grazing pressure in the mature assemblage, indirectly facilitating the persistence of early colonisers (filamentous algae) at late stages of succession. Continuous (dashed) lines indicate direct (indirect) interactions. (+) positive interaction; (-) negative interaction. Redrawn from Benedetti-Cecchi (2000a).

Connell \& Slatyer (1977) stated that "succession never stops" and if the broadest definition of succession as a sequence of colonization following a disturbance event is adopted, then this is certainly the case, especially on rocky shores where both physical and biological disturbance is prevalent. The intermediate disturbance hypothesis (Connell, 1978) has been extensively explored on rocky shores. Sousa (1979b) worked on boulders of different sizes and their likelihood of turning-over from wave action, showing middle-sized boulders experiencing intermediate disturbance had the highest algae diversity. Lubchenco (1978) examined biological disturbance by grazing littorinids in rockpools, finding the highest diversity of algae occurring in pools with intermediate levels of grazing. Intensity of wave action has also been shown to yield a parabolic pattern of species richness, which is lowest at very low disturbance sheltered shores and at exposed shores with very high levels of wave force (Blamey and Branch 2009).

Succession following disturbance is ultimately driven by a combination of physical and biological processes. For example, the intensity of biological interactions may vary in relation to the physical attributes of the disturbed patches. Such interactions were identified by Sousa (1984a) in an elegant experiment in which the removal of gastropod grazers resulted in different patterns of succession depending on the size of the experimental clearings in mussel beds. Small clearings $(25 \times 25 \mathrm{~cm}$ ) were entirely dominated by grazing-resistant encrusting coralline algae. In contrast, large clearings $(50 \times 50 \mathrm{~cm})$ became colonized by fleshy macroalgae in the central part, with encrusting corallines developing only along the borders. Complementary measurements indicated that herbivores were more abundant and foraged mostly along the margins of large patches, whereas they could explore all the available space in small clearings. These patterns were likely a response of grazers to predators and to desiccation stress, both of which were mitigated by the intact mussel assemblage surrounding the disturbed patches. Thus, the central part of large patches offered a refuge from grazing to palatable algae, whereas only grazing-resistant species could survive in areas under the reach of herbivores. Patchy mosaics resulting from local escapes from grazing (tertiary succession) can also lead to higher diversity intertidal landscapes (Hawkins \& Hartnoll, 1983a). 


\section{POSITIVE INTERACTIONS}

Positive interactions between species have been known for a long time, especially in the intertidal zone (Bertness \& Leonard, 1997; Bertness et al., 1999). These can involve habitat provision or amelioration of conditions for other species during succession following disturbance or steady-state conditions. Some of the first experimental work identifying positive interactions was undertaken by Hatton (1938) in France (for reviews, see Connell, 1972; Hawkins et al., 2016). Hatton noted that higher on the shore positive interactions were important, whilst lower down negative interactions such as competition were more prevalent.

More recently, the term "facilitation" borrowed from successional studies has been brought into ecological mainstream studies with work on both rocky shores (Silliman et al., 2011) and saltmarshes (Bertness \& Shumway, 1993; Bertness \& Callaway, 1994; Shumway \& Bertness, 1994). This was formalized by Bertness \& Callaway (1994) in the stress-gradient hypothesis (Figure 3).

Fig. 3. Model of occurrence of positive interactions in in natural communities. Positive interactions are predicted to be rare under mild physical conditions and consumer pressure. Association defences under high consumer pressure, and neighbourhood habitat amelioration under high physical stress lead to a higher frequency of positive interactions. Redrawn from Bertness \& Callaway (1994).

In physically stressed environments, both intra- and interspecific interactions can increase survival and influence demographic processes (Menge \& Sutherland, 1987). In areas with intense biological interactions, co-defences can be important in providing protection. Examples from rocky shores include work in the physically stressed low-humidity environments of Patagonia (Silliman et al., 2011) that emphasised the importance of positive interactions.

Mid-shore canopy-forming algae such as $A$. nodosum enable species to thrive higher up the shore, especially turf-forming algae (Jenkins et al., 1999b, 2004, 2005; Ingólfsson \& Hawkins, 2008; Pocklington et al., 2017). These tend to die when the canopy is removed. The canopy also facilitates persistence of algal turfs that trap sand and inhibit limpet grazing (Airoldi and Hawkins, 2007). Once the canopy is removed, the turf declines and limpet numbers increase (Jenkins et al., 2004). 
Some species can have both positive and negative effects on other species, depending on environmental context and life history stage (Bulleri et al., 2018a). Canopy algae high on sheltered shores can enhance barnacle recruitment, presumably by reducing mortality of recently settled juveniles (Hawkins, 1983). In contrast on more exposed shores, clumps of fucoids can reduce numbers of settling cyprids leading to reduced recruitment (Hawkins, 1983). Lower on sheltered shores, F. serratus prevents settlement by sweeping (Hawkins, 1983; Jenkins et al., 1999a).

Whilst limpets can prevent establishment of fucoids in the northeast Atlantic, once a patch becomes established, juvenile Patella vulgata move under these patches along with adults (Hawkins \& Hartnoll, 1983b; Hartnoll \& Hawkins, 1985). Not only do the limpets benefit from shelter (amelioration of tide-out temperatures and relative humidity), but recent observations and work using isotopes (Davies et al., 2007; Notman et al., 2016) have confirmed that the limpets also eat the fucoids, confirming earlier work (Jones, 1948). Thus, a complex mix of positive and negative interactions plus chance recruitment events help generate and maintain patchiness on moderately exposed shores in the North-east Atlantic (Hawkins et al., 1992). Similar processes have been shown in Australia (Underwood et al., 1983) and on the Pacific Coast of North America (Dungan, 1986).

In recent years, the concept of facilitation cascades has emerged (Stachowicz, 2001; Silliman \& Bertness, 2002), where a species provides habitat for another species that in turn provides habitat for a further species and so on (Stachowicz, 2001). Such cascades are typical of large macroalgae on rocky shores, but have also been described for sessile invertebrates (Peterson \& Heck, 2001; Harley, 2006; Zhang \& Silliman, 2019).

\section{ALTERNATIVE STABLE STATES}

Although the earliest work on alternative stable states focussed on lakes and ponds as model systems (Scheffer et al., 1993; Carpenter et al., 2011; Hawkins et al., 2015), some work has been done in subtidal and intertidal rocky systems. In the shallow subtidal, comparisons between two physically comparable adjacent islands on the west coast of South Africa by Barkai \& McQuaid (1988) led them to argue that their communities existed in alternative stable states, one maintained by the predatory effects of rock lobsters that eliminate many prey species and promote kelp growth because of the absence of grazers, and the other by an unusual predator-prey reversal in which whelks consume and prevent colonisation by lobsters. Sea urchin barrens prompted by overfishing (Steneck et al., 2003) or driven by climate change 
(Ling et al., 2009) have also been considered an alternative stable state. In Cystoseiradominated shallow-water systems in the Mediterranean, storm-driven disturbances, the frequency of which are likely to have increased due to climate change, have been demonstrated to result in alternative stable states (Benedetti-Cecchi et al., 2015). Experiments and models have shown how this system followed non-linear dynamics and exhibited hysteresis (Figure 4), displaying a tipping point at about $70-75 \%$ of canopy loss, beyond which the canopy-dominated communities gave way to those dominated by algal turfs (BenedettiCecchi et al., 2015; Rindi et al., 2017). This experimental work was used to probe statistical early warning signals of an approaching tipping point, such as rising variance and autocorrelation of response variables. Early warning signals of approaching regime shifts have been studied mostly under controlled laboratory conditions or using whole-ecosystem (yet pseudo-replicated) experiments (Carpenter et al., 2011). Rocky shores have proved a tractable system to extend these tests under real world conditions, using properly replicated experiments.

Fig. 4. How alternative stable states or extreme hysteresis can lead to slow or no recovery. Whilst a pulse disturbance can initiate succession or push a system to another state, press disturbance, repeated frequent pulse disturbance, or chronic pollution such as eutrophication or sedimentation can keep a system in another state unless they cease (Benedetti-Cecchi et al., 2019).

There is growing evidence to suggest that urbanisation of coasts, especially increased siltload can also lead to domination by turfs, both in subtidal and intertidal habitats (BenedettiCecchi et al., 2001; Airoldi, 2003; Gorgula \& Connell, 2004). Using long-term observational data and path analysis, (Bulleri et al., 2018b) showed how wave action and anthropogenic disturbance may mediate the biological interactions that regulate regime shifts on rocky reefs in the NW Mediterranean, including canopy-turf interactions and grazing by sea urchins. Indeed, algal canopies, turfs and barrens produced by sea urchins can form complex mosaics on subtidal rocky reefs, suggesting that these assemblages may be organized around three alternative states. Although the interactions that control the shift from one habitat type to another are reasonably well understood, the conditions maintaining the balance among the three putative alternative states have not been fully explored. In particular, improving knowledge of the reinforcing feedback mechanisms that maintain each habitat state is an important area for further research to understand the dynamics of algal-dominated rocky reefs globally. 
Communities dominated by $A$. nodosum canopies in the mid-intertidal of the north Atlantic can be very slow to recover, taking over 20 years in Europe following experimental removal (Burrows, 1947; Jenkins et al., 1999b, 2004; Cervin et al., 2005; Ingólfsson \& Hawkins, 2008; Pocklington et al., 2017), or highly destructive harvesting (Boaden \& Dring, 1980). Experimental work in North America has asserted that ice-scouring leading to loss of $A$. nodosum can lead to an alternative stable state - mussels (Petraitis \& Dudgeon, 1999; Dudgeon \& Petraitis, 2005). This interpretation has been challenged by other workers on New England shores (Bertness et al., 2002). More recently, Menge et al. (2017) revisited sites experimentally cleared in 1974 and showed that Ascophyllum had not as yet recovered 39 years later, the cleared area being dominated by Fucus spp. They concluded that conditions for an alternative state were in operation. On European shores the limited -recovery following $A$. nodosum removal after 20 years has been interpreted as very slow succession, with domination during mid-succession by other fucoids such as $F$. serratus and $F$. vesiculosus for some years. There are intrinsic differences in the biota on shores in New England and the British Isles. Most of the canopy species are the same (A. nodosum, F. vesiculosus, but with $F$. serratus largely absent except in Nova Scotia) and $S$. balanoides is the dominant barnacle in colder regions. However due to differential post-glacial colonization processes, grazing by patellid limpets is absent and Littorina littorea is probably an invasive species in New England (Jenkins et al., 2008b). On the shores studied by Petraitis and Dudgeon (1999), mussels dominated the alternative state, but they were generally absent from $A$. nodosum-dominated shores in northwest Europe. Context may play a role in whether alternative stable states occur or not. Such apparently stable states might still be an outcome of extremely slow succession, especially given the generally low recruitment of $A$. nodosum in some systems (Åberg \& Pavia, 1997). Very strong inhibition may, therefore, occur by species present in intermediate successional stages. Given the estimated lifespan of individual A. nodosum of over 100 years, it is not surprising that succession is slow given that their dominance is maintained by vegetative proliferation of clump-forming genetic individuals (Åberg, 1996).

\section{BIODIVERSITY AND ECOSYSTEM FUNCTIONING}

The realization that biodiversity could drive the functioning of ecosystems has been a major topic of interest in mainstream ecology for the last three decades (Loreau et al., 2002), having been explored in terrestrial (Hector et al., 1999; Loreau et al., 2001), freshwater (Giller et al., 2004; Woodward, 2009) and marine ecosystems (Solan et al., 2012). Most work in marine ecosystems has used synthetic assemblages of species from soft sediment communities in mesocosms (Emmerson et al., 2001; Solan et al., 2008), strongly linking diversity to ecosystem processes such as nutrient remineralisation (Emmerson et al., 2001). Some 
pioneering work in the field on rocky shores explored the influence of biodiversity on primary production, showing strong idiosyncratic effects of individual dominant species such as Patella (O'Connor \& Crowe, 2005). Rockpools have been used as semi-enclosed mesocosms in the field enabling ecosystem processes such as primary productivity to be measured as a response variable (Noël et al., 2009), whilst manipulating diversity in the pool at the species or functional group level (Griffin et al., 2010).

Rocky shore organisms have also been taken into the laboratory and experimentally assembled in mesocosms mimicking rock pools. Griffin et al. (2008) investigated the interaction of diversity and density in assemblages of predatory crabs. They showed the importance of considering density in such experimental work; predators were shown to occupy distinct fundamental niches but loss of predator diversity impacted ecosystem processes only at high predator densities. Using a similar mesocosm approach, the influence of spatial heterogeneity on the role of biodiversity was shown in assemblages of grazing gastropods (Griffin et al., 2010). More complex mesocosms have been used to investigate the effect of predator diversity on subtidal food webs, showing that changes in the diversity of predatory fish can cascade to lower trophic levels by reducing grazer abundance, which in turn translates to different levels of increases in algal biomass (Bruno \& O'Connor, 2005). Experiments by O'Connor et al., (2013) compared the influence of loss predators and independent manipulations of lower trophic level grazers on algal composition and biomass on exposed and sheltered shores. Cascading negative effects of predator loss were identified on grazers and indirect effects on primary producers, mediated by grazer identity.

The diversity of functional groups within a habitat has been suggested to be important in determining the invasibility of assemblages (Arenas et al., 2006). Using mosaics of tiles in rock pools with different diversity and assemblage compositions, Arenas et al. (2006) showed that invasibility may be facilitated by the disappearance of whole functional groups, which is increasingly likely with human activity.

Whilst biodiversity has been demonstrated to have a role in shaping ecosystem processes, this has mainly been shown in closed systems - often artificially, such as in mesocosms. More attention has focussed on biodiversity at the numbers and types of species level. In open highly-fluid systems typical of most marine ecosystems, especially rocky shores, habitat patch diversity may be more important (Hawkins, 2004; Giller et al., 2004). This will influence the balance of primary producers, consumers such as filter feeders, predators and mosaics of hard substrata dominated by production processes and soft sediments as the primary site for remineralisation and carbon sequestration. There will also be export and import of material 
between these habitat patches. Alsterberg et al. (2017) demonstrated this in sedimentary systems. Recent work on rocky shores has also emphasized the strong context-dependency of biodiversity-ecosystem functioning relationships (Mrowicki et al., 2015), reminding us of the importance of environmental gradients (summarised in Raffaelli \& Hawkins, 1996) in setting patterns and ultimately determining potential composition of biodiversity, outcomes of interactions and hence processes at the community and ecosystem level (Hawkins et al., 2019b; Hawkins et al., 2019c).

\section{BOTTOM-UP FORCING AND TOP-DOWN CONTROL}

The limnological and oceanographic research communities have long pondered the importance of bottom-up forcing by physico-chemical processes relative to top-down control by higher trophic levels. These concepts can be best explored in closed systems such as small lakes and ponds where bottom-up nutrients and top predators can both be manipulated at the scale of the whole ecosystem in very similar adjacent lakes, ponds or large mesocosms (Scheffer et al., 1993; Moss et al., 1994; Williams et al., 2002).

These concept of bottom-up forcing has been explored in intertidal ecosystems, especially those strongly influenced by nutrient-rich upwelling on the Pacific coasts of North America (Menge, 2000a; Menge \& Menge, 2013; Fenberg \& Menge, 2019), New Zealand (Menge et al., 1999), Chile (Wieters et al., 2003; Wieters, 2005; Reddin et al., 2015), and South Africa from the Atlantic to the Indian Ocean (Bustamante et al., 1995a; Bustamante \& Branch, 1996; McQuaid \& Lindsay, 2000). Bottom-up forcing by greater nutrient supply can lead to greater productivity by both microbial biofilms and macro-algae on the shore, leading to faster growth and larger sizes of grazers and greater densities of filter feeders (Bustamante et al., 1995a, b). Similarly, rich inshore phytoplankton can enhance growth of sessile filter feeders (Bertness et al., 1991; Xavier et al., 2007), especially if it proliferates during upwelling events and is then transported onshore by downwelling, coined the intermittent upwelling hypothesis (Menge \& Menge, 2013). This in turn can support larger numbers of predatory animals. Larval supply can also be viewed as a form of bottom-up forcing as it intensifies both intraspecific (Jenkins et al., 2008a) and interspecific interactions (e.g. competition in high recruitment areas such as the Firth of Clyde, Connell, 1961b) as well as providing more food for predators.

Using both comparative studies and field experiments, research on South African west-coast islands that are occupied by dense colonies of seabirds has shown that guano boosts nutrient levels in the surrounding seawater. This elevates intertidal algal growth and infaunal abundance, thus respectively increasing food supplies for herbivores and waders such as 
turnstones. As a consequence of enhanced algal biomass, growth rates and sizes of limpets rise substantially. However, oystercatchers reach greater abundance on the islands because they are protected there from predators, and they exert a strong influence on limpet abundance, micro-habitat occupation and grazing; and smaller waders deplete the infauna of algal mats on a seasonal basis determined by their migration patterns (Hockey \& Underhill, 1984; Branch, 1985; Bosman et al., 1986). Bottom-up nutrient effects are thus countered to some extent by top-down predation.

Conversely the role of top-down control by predators (Paine, 1966) and grazers (Jones, 1946, 1948) has been long known in intertidal systems with some of the first demonstrations of how lower trophic levels can be controlled. If bottom-up forcing is great then lower trophic levels can escape or swamp top-down control, especially if predation is constrained by water flow or wave action (Leonard et al., 1998); but then in species like barnacles which hummock, intense intraspecific competition can lead to mass mortality (Barnes \& Powell, 1950).

In many cases the relative importance of top-down control and bottom-up forcing is a balance, varying from place to place with mesoscale hydrography and coastal morphology (Menge, 2000a). It can also change temporally with season in temperate zones, or with intensity of upwelling in boundary current dominated systems. In the plankton in temperate regions physico-chemical factors control primary production in the winter (low light, much turbulence even though nutrients are not limiting). With increased light in spring and a less turbulent water column due to stratification, phytoplankton can bloom, this being ended by a combination of lack of nutrients coupled with grazing by copepods that lag the phytoplankton bloom. Similar processes have been shown in cold-temperate intertidal rocky shores on the Isle of Man that are driven by microbial films (Thompson et al., 2004). In the winter light is limiting but in late winter/early spring as light increases there is an increase in biomass as shown by chlorophyll. Grazing activity is driven by temperature and is still low in February/March at the time of coldest sea temperatures enabling a window of opportunity for benthic diatoms to flourish. Later in the year this bloom is halted by increased grazing as well as light and desiccation stress, leading to cyanobacterial domination in the summer. In parallel experiments by Thompson et al. (2004) showed the primacy of grazing and seasonal summer stresses over nutrient forcing, suggesting both bottom-up forcing, top-down control and what they termed lateral stresses were important in this simple system (see Figure 5). Thus, there is interplay between abiotic factors (some bottom-up, some modulating stresses) and biological control in this highly seasonal system. 
Experimental work in rock pools (Masterson et al., 2008) has shown the interactive effects of top-down control by grazers and bottom-up nutrient enrichment on early successional algal assemblages following disturbance, with composition, cover and community productivity being used as response variables. Negative effects of grazing tended to over-ride positive effects of nutrient-forcing, except at peak algal growth when top-down control was swamped. Interestingly nutrient levels had an important influence on the identity of dominant macroalgae, leading to a mismatch between effect estimates based on cover and those based on productivity. While loss of grazers under ambient nutrient conditions led to high cover estimates (mainly of red algae such as Ceramium) but little enhancement of productivity, under elevated nutrients ephemeral green algae were favoured leading to a three-fold increase in productivity.

Fig. 5. Bottom-up forcing and top-down control of microbial films on rocky shores in the Northeast Atlantic: (a) Regulation of the balance between producers (photosynthetic microbiota) and consumers (grazers) in the rocky intertidal during summer and winter. The positive (+) and negative (-) lateral effect of contrasting physical factors on bottom-up and top-down control of trophic interactions are illustrated. Strong effects are shown as solid lines, weak effects as dashed lines. (b) Conceptual model incorporating the role of physical stresses operating laterally at all trophic levels (sideways-facing arrows) together with bottom-up forcing (physical and chemical limiting factors; upward arrows) and top-down control (predation and grazing; downward arrows) in regulating community structure on temperate rocky shores (Thompson et al., 2004).

\section{OVERVIEW AND SYNTHESIS}

\section{Concepts and experiments}

The above examples show how important experiments have been in understanding how patterns on rocky shores are shaped by processes (see various chapters in Hawkins et al., 2019a), but also, perhaps more importantly, how rocky shore experiments have contributed to the ecological mainstream across a range of concepts. The papers by Menge \& Sutherland $(1976,1987)$ perhaps epitomize the link between theory and empirical experimentation, taken further forward by Menge (2000a). Menge \& Sutherland (1976) synthesized how environmental gradients of tidal elevation and exposure to wave action influenced the outcomes of interactions, especially the respective roles of competition, predation and what they at the time called temporal heterogeneity (in essence what now would be called disturbance). This synthesis was re-visited in Menge \& Sutherland (1987), who clarified the role of disturbance (perhaps prompted by the work of Sousa, 1984b) and considered the 
importance of recruitment regimes as the importance of supply-side processes re-surfaced in the 1980s (Underwood \& Fairweather, 1989). Menge (2000a) then considered how top-down control and bottom-up forcing could be incorporated to enhance understanding. He emphasized how environmental context on various spatial and temporal scales can influence how shore communities are structured - particularly by mesoscale nearshore oceanographic features such as upwelling influencing both productivity (Bustamante et al., 1995b; Wieters et al., 2003; Xavier et al., 2007) and larval delivery (Pineda, 1991).

As Menge (2000a) pointed out: theory helps ecologists rise above a morass of local and idiosyncratic natural history studies enabling a predictive framework and some generalization. At the very least theory provides the concepts and vocabulary to formulate hypotheses and interpret experimental results. However, papers emphasizing the contextual nature of many ecological processes (Crowe et al., 2011; O'Connor \& Donohue, 2013) are, perhaps, a warning about not overgeneralizing. Good natural history is essential in experimental ecology (Hawkins et al., 2016): it is often the first phase in exploring pattern by observation and getting to know traits of species. It helps stratify surveys and experimental designs and minimize variance influencing factors being tested experimentally and can help get rid of co-variance. Good natural history leads to more elegant experimentation; just as good physiology depends on expertise in morphology and anatomy.

\section{Approach and methodology}

The most important development in the last 30 years has been better experimental designs matched with appropriate statistical analyses in a formal hypothesis-testing framework. The seminal work of Hurlbert (1984) on pseudo-replication made ecological studies more demanding and forced the ecological community to think more carefully about the nature and the design of ecological studies. Considerable progress has been made in this direction and for this Underwood can take much of the credit (Underwood, 1978, 1981; Underwood \& Chapman, 1985). Underwood with Chapman have educated young experimental ecologists world-wide, calling for more rigour and logic in the way experiments are designed, conducted, analysed, and interpreted. Underwood's work on the scientific method has made Popperian falsification widely accessible, defining an operative framework whereby observations, theories (models), hypotheses (predictions) and experiments are logically connected (Underwood, 1981, 1997; Underwood \& Denley, 1984). The framework offers a decisionmaking tool to arbitrate among alternative explanations and to eradicate false models, contributing to pursuing values of objectivity when interpreting the outcome of ecological experiments and observational studies. By emphasizing the cyclical nature of observations, models, hypotheses, and experiments, the approach advocated by Underwood has disclosed 
the complexity of rocky shores in an unprecedented way, documenting variation in the structure of assemblages over multiple scales in space and time and challenging the assumed generality of many ecological processes. This work has spilled beyond the boundaries of rocky shore ecology and has influenced the work of peers in other fields as well. It has also stimulated better sampling designs to assess ecological impacts through beyond-BACI (Before-After/Control-Impact) sampling designs (Underwood, 1991b, 1992b, 1994). The Underwoodian approach has demonstrated the value of looking beyond the most obvious explanations, showing the power of disproving alternative models to break paradigms, eradicate myths and disclose the unexpected.

Focus on rigorous experimental design has allowed interactions between multiple factors to be disentangled plus encouraged hierarchical designs that test for generality over spatial scales (e.g., Coleman et al., 2006). Ease of testing multi-variate data, for example, packages such as PRIMER with the PERMANOVA extension (Anderson et al., 2008), and free $R$ software (R Core Team, 2019) have led to much more complex and effective statistical analyses. Nevertheless, increasing availability of libraries and functions to perform complex analyses may also lead to mistakes and abuse of statistics. Only the judicious choice and correct use of well understood methodologies will guarantee progress and ensure that the ecological community can take full advantage of the increasing availability of open statistical software.

New technological approaches in the last two decades such as digital photography, remote sensing, better and cheaper GPS, and online identification resources, have greatly increased the scope of what can be done between tides. Digital photography has revolutionised nondestructive sampling enabling much greater sample sizes, and faster processing of acquired images back in more clement environment of the laboratory. Cheap and robust underwater cameras can provide insights into tide-in conditions, especially presence and activities of mobile predators (Silva et al., 2008; Harasti et al., 2014). In situ sensors, data loggers, and remote sensors can characterise the environment, especially temperatures, experienced at fine temporal and spatial scales over long periods and help better define environmental gradients and micro-scale mosaics of conditions (Lima \& Wethey, 2009; Seabra et al., 2011). Thus, the context of experimental manipulations can be much better described. Hard-toaccess areas have become more accessible through the use of remote sensing technologies such as satellites and aerial photography using drones (Guichard et al., 2000; Brodie et al., 2018; Gomes et al., 2018; Rosenthal et al., 2018). The ability to collect large numbers of images over a wide area has enabled assessments of species distribution and temporal and spatial fluctuations, such as examining distribution patterns of mussels in Portugal (Gomes et 
al., 2018) and investigating changes in kelp forests over time on a global scale (Rosenthal et al., 2018). Incorporating remote sensing techniques into experimental design has applications for investigating large scale impacts of disturbance on rocky shores, such as commercial macroalgal harvesting (Bennion et al., 2018), oil spills (see Gilfillan et al., 1995; Mishra et al., 2012 for examples on coastal marshes) and earthquakes (Schiel et al., 2019b).

Ease of access to rocky shores has made them amenable to citizen science, where volunteers carry out scientific tasks (Delaney et al., 2008; Dickinson et al., 2012; Vye et al., 2020) such as sample collection, processing, and analysis. This is not a new concept, with examples of bird surveys that have been done by citizen scientists for over 100 years (Silvertown, 2009). This approach is becoming more common in marine and coastal environments (Hughes et al., 2014; Cigliano \& Ballard, 2017) and is increasingly being used to support policy and management (Hyder et al., 2015; Townhill \& Hyder, 2017). For rocky shores, most examples relate to observations, monitoring, or biodiversity (Delaney et al., 2008; Vye et al., 2020), but more recently experimental approaches (e.g. www.capturingourcoast.co.uk) and internetbased citizen science (e.g. www.zooniverse.org, Newman et al., 2012) have become more common. With care this can also include simple experimental procedures such as recolonization or clearance experiments at multiple locations with appropriate controls. Obviously, there are training, ethical, conservation and quality-control issues to be overcome, but the scope is limitless for both describing pattern and understanding process on broad spatial scales.

New spectroscopic approaches have also recently revolutionized intertidal ecology. Biomass of photosynthetic biofilms can be measured non-destructively and over much greater spatial extents (Murphy et al., 2005, 2006), than with traditional destructive chlorophyll extraction techniques (Underwood, 1984; Hill \& Hawkins, 1990; Nagarkar \& Williams, 1997; Thompson et al., 1999). They have enabled photosynthesis of macro-algae to be measured including stress responses (Ferreira et al., 2014).

Technological innovation for the acquisition, storage and dissemination of digital information makes large environmental and biological datasets increasingly available. This boost from large datasets opens new opportunities for ecological analysis at unprecedented spatial and temporal scales. Recent developments have encouraged a synthesis between observations and experiments using hybrid datasets resulting from the combination of observations and experiments (Benedetti-Cecchi et al., 2018). This approach leverages the scope of large-scale observational data with the ability to attribute causality typical of experimental studies. Large datasets are mostly observational, but distributed experiments across large spatial scales are 
becoming increasingly common (see Sanford \& Bertness, 2009, for review). Building on recent developments in time-series analysis and spatial modelling, hybrid datasets can take advantage of the data generated by distributed experiments embedded in large-scale observation networks combining observational and experimental data provide a promising approach to uncover causal relations in large-scale phenomena, beyond the limits to causal inference inherent in observations and beyond the scales encompassed by individual manipulative experiments.

The development of ever-more sophisticated and well-controlled mesocosms mimicking rock pools have allowed more controlled factorial experiments to understand how complex interactions between biodiversity loss and elements of global change (including rising temperatures, stormier seas, the introduction of non-native species and eutrophication) modify community composition and ecosystem functioning. Whilst strictly not field experimentation, such approaches have stemmed from work on rocky shores in general and rock pools in particular whether natural or drilled on the shore (Arrontes \& Underwood, 1991; Atalah \& Crowe, 2010). Such mesocosms have been particularly powerful in disentangling the effects of multiple stressors or environmental context crossed with biodiversity loss (e.g., O'Connor et al., 2015 - biodiversity loss and nutrient enrichment; Mrowicki \& O'Connor, 2015 - wave action on warming and biodiversity loss; White et al, 2018 - biodiversity of predators with warming and nutrient enrichment; Vye et al., 2014 - impacts of invasive species with water temperature and nutrient enrichment).

One of the criticisms of experimentation is that it is often done on very local scales. Broaderscale insights can come from rapid response to large cataclysmic events whether from major acute pollution incidents such as oil-spills (Southward \& Southward, 1978; Hawkins et al., 2017a,b), nuclear weapon testing lifting whole atolls (Lebednik, 1973) or major tectonic events, particularly earthquakes. Earthquakes in Chile (Castilla \& Oliva, 1990), Mexico (Bodin \& Klinger, 1986) and New Zealand (Schiel et al., 2019b) have provided insights into diverse topics such as factors setting zonation patterns due to uplift or submergence of coastal rock platforms, as well as connectivity during recolonization. Whether from acute pollution incidents such as oil-spills, outbreaks of pandemic disease such as COVID 19 reducing tourism and recreational use of the foreshore, or natural disasters such as earthquakes or tsunamis, insights come best when they impact well-studied sites with previous time-series data, ideally where experimentation has revealed some of the processes causing pattern. The network of sites studied by the Southwards for a decade before the Torrey Canyon oil spill (Southward \& Southward, 1978) provided an unintended beyond-BACI design of multiple impacted and unimpacted areas beyond the influence of the spill - ultimately allowing some disentangling of 
the impacts of the spill and the role of climate fluctuations in recovery processes (Hawkins et al., 2017a,b). Likewise in New Zealand the work at Kaikoura over many years by Schiel and colleagues will enable some major scientific insights to be recovered from the wreckage caused by the earthquake (Schiel et al., 2019b), including the closure of the laboratory at Kaikoura.

\section{Conservation and management of rocky shores in a rapidly changing world}

Understanding from experiments has also contributed to better conservation and management of rocky shore ecosystems (Thompson et al., 2002; Branch et al., 2008) including the use of rocky shore organisms as indicators of global change and understanding interactions with more regional and local scale impacts (explored in detail in Branch et al., 2008; Hawkins et al., 2019c). Here we focus mainly on global change, but emphasize that many of its more pernicious impacts are usually in concert with regional or local scale impacts such as overfishing of nearshore predators (Ling et al., 2009) or over-collection of intertidal grazers (Borges et al., 2015), sediment and nutrient run-off from land both from agricultural (Schiel \& Howard-Williams, 2016) and urban sources (Airoldi, 2003), and habitat loss and fragmentation (Airoldi \& Beck, 2007), often as a result of urbanisation or ocean sprawl (Bugnot et al., 2020, Hawkins et al., 2020).

Ecosystem responses to climate change fluctuations (Southward, 1967: Southward \& Crisp, 1954) and subsequent rapid climate change have been detected using rocky shore indicators (Southward et al., 1995; Hawkins et al., 2003; Mieszkowska et al., 2006, 2014). Knowledge of species interactions derived from experiments have shown the importance of modulation of climate warming by biological interactions. Based on the classical work of Connell (1961a), coupled with a space-limited model (Roughgarden et al., 1985; Poloczanska et al., 2008), modelling has shown how responses of cold-water and warm-water species of barnacles to climate were mediated by competition. In warmer years, the warm-water Chthamalus spp. prospered as they were released from competition with faster growing northern species. Predictive models using climate change scenarios only worked well when competition in addition to physical drivers were built into the models. Experiments have been used to explore how competitive interactions can be shaped by additional species expanding polewards in response to climate change (Firth et al., 2009). How facilitation can modulate stresses resultant from climate change for mobile animals such as limpets has been shown by Moore et al. (2007), finding lower survival of the northern species, $P$. vulgata, when clumps of Fucus were removed, unlike the more southern $P$. depressa that does not aggregate under algal clumps. Changes in the species composition of these two species have implications for the dynamic patchiness on rocky shores (Hartnoll \& Hawkins, 1985; Hawkins et al., 2008). 
Thinning of fucoid canopies resulting from climate change (Hawkins et al., 2009; Yesson et al., 2015) has been experimentally simulated and can lead to reductions in sub-canopy species (Pocklington et al., 2017). Positive interactions have been advocated as a tool to combat loss of biodiversity in the face of climate change (Bulleri et al., 2018a). Experimentally derived knowledge has also enabled the impacts of oil spills and their subsequent clean up to be better understood (Southward \& Southward, 1978; Hawkins \& Southward, 1992; Hawkins et al., 2017a, b).

Extreme events such as hurricanes, marine heatwaves and floods are predicted to become more frequent with climate change (Easterling et al., 2000; Oliver et al., 2018). Climate models also predict that extreme events are becoming more clustered in time, which implies a change in the distribution of time intervals between consecutive disturbance events compared to historical climate scenarios (Easterling et al., 2000). Experimental work has been performed to assess the ecological effects of changing the intensity and temporal distribution of perturbations on rocky shore assemblages. Some studies have done so by manipulating the frequency of events. This approach allows a direct test of the ecological effects due to the expected increased frequency of extreme events. However, manipulating the frequency of perturbations has the drawback of confounding intensity with temporal variability (clustered vs. regularly distributed) of perturbations (Benedetti-Cecchi, 2003). Appropriate experimental designs have been proposed to disentangle the effects of changes in mean intensity from those due to variation in the temporal patterning of events, also allowing tests of interactions between intensity and degree of temporal clustering of perturbations (Benedetti-Cecchi, 2000b, 2003).

These designs have been used to assess the impacts of waves (Bertocci et al., 2005; 2010; Maggi et al., 2012), desiccation stress (Benedetti-Cecchi et al., 2006), sediment regimes (Vaselli et al., 2008), and heatwaves (Dal Bello et al., 2017) on rocky intertidal assemblages. Overall, the results have shown that the effects of increasing intensity of perturbations can be offset in part by increasing degree of temporal clustering. In other words, regardless of the nature of the perturbation, results have shown that the temporally clustered events are in general less detrimental to rocky shore assemblages that events that are more regularly distributed in time. Interestingly, an observational study on the impact of hurricanes on coral reefs in the Caribbean has shown a similar pattern: impacts were less severe in years when hurricanes occurred clustered in time compared to years when they were regularly distributed (Mumby et al., 2011). 
The mechanisms behind this apparent general positive effect of temporal clustering of perturbations have not been elucidated yet, but one possibility is that a clustered perturbation scenario allows for longer periods of recovery compared to where the same number of perturbations are distributed regularly over the same time window. A longer period of recovery may be particularly advantageous if individual perturbations are intense enough so that one event is sufficient to wipe out most of the organisms from an area. In this scenario the cumulative effect of a cluster of perturbations will not be much more different from that of an individual one. Regardless of the specific mechanism, a positive response to increased clustering of extreme climate events injects some optimism in the ability of rocky shore assemblages to cope with the expected increase in intensity (and temporal clustering) of climate-related perturbations.

The zonation of intertidal organisms has been shown by observations and experiments to be squeezed from environmental extremes such as desiccation stress at the top of the shore coupled with greater consumer pressure from lower down due to biogeographic shifts (e.g. colder water fucoids in the Azores stressed by more frequent warmer weather and the spread of herbivorous fish northwards, Martins et al., 2019). Late winter and early spring seasonal blooms of light-driven micro-algae and macro-algae are likely to get curtailed by earlier onset of temperature-driven grazing pressure (Thompson et al., 2004) as has been shown on latitudinal gradients in Europe (Jenkins et al., 2000).

Experimental approaches have informed both ecological enhancement of highly modified urban coastlines as well as adaptational responses to climate change by design of environmentally-sensitive sea defences in the face of rising and stormier seas (Morris et al., 2019). Ironically, early studies of artificial structures used them primarily as simple surrogates of natural systems with low topographic complexity and hence ease of study - in many cases cubist rocky shores. Examples include describing distribution patterns in relation to tidal height and wave exposure (Southward \& Orton, 1954), plus succession on large breakwater blocks of known age (Hawkins et al., 1983) both using Plymouth Breakwater. The importance of grazing interactions in limiting the lower limit of kelp in the shallow subtidal zone was shown on the ruined breakwater in Port Erin, Isle Of Man (Jones \& Kain, 1967). Interactions between barnacles and limpets (Hawkins \& Hartnoll, 1982b; Santini et al., 2019) settlement patterns of barnacles in relation to wind patterns (Hawkins \& Hartnoll, 1982a) were all investigated on the same Raglan Pier in Port Erin. The simplicity of replicated artificial shore parallel breakwaters at Elmer in Sussex, UK, enabled the respective roles of grazing by limpets in preventing establishment of fucoid algae and wave action reducing persistence of older plants to be disentangled by a combination of field experiments and modelling (Jonsson et al., 2006). 
The full battery of experimental approaches has been deployed to better understand the efficacy of various interventions to enhance biodiversity and deliver ecosystem services on artificial hard substrate habitats in ports and on sea defences - an approach now termed ecoengineering. Much of this work has been led from Sydney Australia, with the development of artificial rockpools (Browne \& Chapman, 2011) and boulder-fields (Chapman, 2017), including better understanding of the diversity deficit typical of artificial communities compared to natural ones (Bulleri \& Chapman, 2010). Similarly in Europe the outcomes of experimental ecology was used in early efforts to inform guidelines on the design of sea defences (Moschella et al., 2005; Burcharth et al., 2007), understanding their impacts (Martin et al., 2005), enabling putting this work into a broader ecological and conservation context (Airoldi et al., 2005). This early work has proliferated to understand the impacts of what became known as ocean sprawl (Duarte et al., 2012; Firth et al., 2016; Bugnot et al., 2020; Hawkins et al., 2020) and how these impacts can be at least be partially offset by eco-engineering interventions (Dafforn et al 2015; Morris et al., 2019). Worldwide experimental trials have tested the efficacy of different types of crevices (Coombes et al., 2015, complexity of tiles (Loke et al., 2014; Loke et al., 2015), boulder size and mix in gabions (Firth et al., 2014) and retro-fitted artificial rockpools (Browne \& Chapman, 2014; Evans et al., 2016). Guidelines on practice are emerging (Morris et al., 2019; O'Shaughnessy et al., 2019) and this approach is now entering the planning (Evans et al., 2016; Evans et al., 2019) and engineering mainstream (Burcharth et al., 2007). Additionally along the way some interesting insights have emerged on rock pool ecology (Firth et al., 2013), topographic complexity and diversity (Loke et al., 2016; Loke \& Todd, 2016), mobile predators using the intertidal zone (Morris et al., 2017), connectivity of matter and propagules (Bishop et al., 2017; Heery et al., 2017) plus difficult-to-study boulder shores (Chapman, 2017). Furthermore, understanding of the nature of biogeographic boundaries has resulted with breakwaters acting as "experimental" stepping-stones, enabling range expansions (Hawkins et al., 2009; Keith et al., 2011; Firth et al., 2015) - an experiment that no ethical committee would ever allow (Sugden et al., 2009), nor would a funding body finance.

\section{Concluding Comments}

Experiments on rocky shores have contributed to both ecological theory and better understanding of pattern and process in coastal ecosystems. It is now informing responses to global change and creeping urbanization. The coastal zone is getting increasingly squeezed and impacted by both development and climate-driven change. Experiments help explain pattern and can feed into forecast and prediction of future states. They can also inform better understanding and hence management of the interactions of multiple regional and local-scale impacts with global change. 


\section{Acknowledgements}

SJH, LBC, SRJ, KH wish to thank the European-funded project EUROROCK which enabled us to all work together in such a fruitful and fun way, and was an important step in all our careers. EUROROCK was shaped by advice from Tony Underwood in its conception, experimental designs and reinforced by training received by the team from him and Gee Chapman. Eurorock's co-ordinator Guido Chelazzi herded cats well. SJH would also like to thank all his PhD students and Post-doc Fellows hosted, especially Richard Thompson, Nova Mieszkowska, Louise Firth, Mike Burrows, Mark Johnson, Ross Coleman, Tasman Crowe, Paula Moschella, Ally Evans who have helped him do much work and have been great fun on the shore and pub over the years. SJH would like to thank the Marine Biological Association of the UK for hosting his NERC-funded post-doc in 1979-1980 and providing lab space on subsequent visits from Manchester, Port Erin, Southampton, Bangor, allowing me to be Director from 1999 to 2007 and according me the privilege of a Lankester Research Fellowship as an Emeritus from Southampton - plus an office. SJH has a large personal and professional debt to Richard Hartnoll who helped get him a NERC studentship on experimental ecology and spotted the value of such an approach and helped finish many things off and get them published. George Russell always took an interest and introduced him to limpet-algal interactions on a fieldcourse in 1975. Alan Southward was a great inspiration and mentor for nearly 40years - we dedicate this review to him - and we are sure he would have had some trenchant criticisms ("too much theory and jargon"). SJH, SRJ and $\mathrm{KH}$ all benefitted from the unique atmosphere at Port Erin Marine Laboratory/ Marine Biological Station (RIP). Over the years SJH has received a personal appeal NERC studentship, personal Post-doc Fellowship, and many grants and studentships from NERC, plus NERC grant-in-aid to the MBA (19992007). SRJ similarly received a NERC studentship and has been subsequently funded by them including grants, studentships and held a NERC grant-in-aid funded Fellowship at the MBA.

We all thank Jane Lewis for this invitation to write this review and her patience. The review has benefitted from expert input from two referees: David Schiel and George Branch who contributed much.

\section{REFERENCES}

Åberg P (1992) Size-based demography of the seaweed Ascophyllum nodosum in stochastic environments. Ecology 73, 1488-1501.

Åberg P (1996) Patterns of reproductive effort in the brown alga Ascophyllum nodosum. Marine Ecology Progress Series 138, 199-207. 
Åberg P and Pavia H (1997) Temporal and multiple scale spatial variation in juvenile and adult abundance of the brown alga Ascophyllum nodosum. Marine Ecology Progress Series 158, 111-119.

Aguilera MA and Navarrete SA (2007) Effects of Chiton granosus (Frembly, 1827) and other molluscan grazers on algal succession in wave exposed mid-intertidal rocky shores of central Chile. Journal of Experimental Marine Biology and Ecology 349, 84-98.

Aguilera MA and Navarrete SA (2012) Functional identity and functional structure change through succession in a rocky intertidal marine herbivore assemblage. Ecology 93, 7589.

Aguilera MA, Navarrete SA and Broitman BR (2013) Differential effects of grazer species on periphyton of a temperate rocky shore. Marine Ecology Progress Series 484, 6378.

Aguilera MA, Broitman BR, Vásquez JA and Camus PA (2019a) Consumer-resource interactions on an environmental mosaic: the role of top-down and bottom-up forcing of ecological interactions along the rocky shores of the temperate south-eastern Pacific. In Hawkins, SJ, Bohn, K, Firth, LB and Williams, GA (eds) Interactions in the marine benthos: Global patterns and processes. Cambridge University Press, pp. 307332.

Aguilera MA, Valdivia N, Jenkins SR, Navarrete, SA and Broitman BR (2019b) Asymmetric competitive effects during species range expansion: an experimental assessment of interaction strength between 'equivalent' grazer species at their range overlap. Journal of Animal Ecology 88, 277-289.

Airoldi $\mathbf{L}$ (2003) The effects of sedimentation on rocky coast assemblages. Oceanography and Marine Biology: An Annual Review 41, 169-171.

Airoldi L and Beck MW (2007) Loss, status and trends for coastal marine habitats of Europe. Oceanography and Marine Biology: An Annual Review 45, 345-405.

Airoldi L and Hawkins SJ (2007) Negative effects of sediments on grazing activity and survival of the limpet Patella vulgata L. Marine Ecology Progress Series 332, 235-240.

Airoldi L, Abbiati M, Beck MW, Hawkins SJ, Jonsson PR, Martin D, Moschella PS, Sundelöf A, Thompson RC and Åberg P (2005) An ecological perspective on the deployment and design of low-crested and other hard coastal defence structures. Coastal Engineering 52, 1073-1087.

Alsterberg C, Roger F, Sundbäck K, Juhanson J, Hulth S, Hallin S and Gamfeldt L (2017) Habitat diversity and ecosystem multifunctionality-The importance of direct and indirect effects. Science advances 3, e1601475.

Anderson MJ, Gorley RN and Clarke KR (2008) PERMANOVA+ for PRIMER: Guide to software and statistical methods. Primer-E. Plymouth, UK.

Archambault P and Bourget E (1996) Scales of coastal heterogeneity and benthic intertidal species richness, diversity and abundance. Marine Ecology Progress Series 136, 111 121.

Arenas F, Sánchez I, Hawkins SJ and Jenkins SR (2006) The invasibility of marine algal assemblages: role of functional diversity and identity. Ecology 87, 2851-2861.

Arrontes $\mathbf{J}$ and Underwood AJ (1991) Experimental studies on some aspects of feeding ecology of the intertidal starfish Patiriella exigua. Journal of Experimental Marine Biology and Ecology 148, 255-269.

Arrontes J, Arenas F, Fernandez C, Rico JM, Oliveros J, Martinez B, Viejo RM and Alvarez D (2004) Effect of grazing by limpets on mid-shore species assemblages in northern Spain. Marine Ecology Progress Series 277, 117-133.

Atalah J and Crowe TP (2010) Combined effects of nutrient enrichment, sedimentation and grazer loss on rock pool assemblages. Journal of Experimental Marine Biology and Ecology 388, 51-57.

Audouin JV and Edwards HM (1833) Classification des Annélides, et Description de celles qui habitent les côtes de la France. Annales des sciences naturelles : comprenant La physiologie animale et végétale, l'anatomie comparée des deux règnes, la zoologie, la botanique, la minéralogie et la géologie 28, 187-247. 
Baker SM (1909) On the causes of the zoning of brown seaweeds on the seashore. New Phytologist 8, 196-202.

Baker SM (1910) On the causes of the zoning of brown seaweeds on the seashore. New Phytologist 9, 54-67.

Barkai A and McQuaid C (1988) Predator-prey role reversal in a marine benthic ecosystem. Science 242, 62-64.

Barnes H (1956) Balanus balanoides (L.) in the Firth of Clyde: the development and annual variation of the larval population, and the causative factors. The Journal of Animal Ecology, 72-84.

Barnes H and Powell HT (1950) The development, general morphology and subsequent elimination of barnacle populations, Balanus crenatus and $B$. balanoides, after a heavy initial settlement. Journal of Animal Ecology 19, 175-179.

Benedetti-Cecchi $\mathbf{L}$ (2000a) Predicting direct and indirect interactions during succession in a mid-littoral rocky shore assemblage. Ecological Monographs 70, 45-72.

Benedetti-Cecchi L (2000b) Variance in ecological consumer-resource interactions. Nature 407, 370-374.

Benedetti-Cecchi L, Acunto S, Bulleri F and Cinelli F (2000) Population ecology of the barnacle Chthamalus stellatus in the northwest Mediterranean. Marine Ecology Progress Series 198, 157-170.

Benedetti-Cecchi L, Pannacciulli F, Bulleri F, Moschella PS, Airoldi L, Relini G and Cinelli F (2001) Predicting the consequences of anthropogenic disturbance: largescale effects of loss of canopy algae on rocky shores. Marine Ecology Progress Series 214, 137-150.

Benedetti-Cecchi $\mathbf{L}$ (2003) The importance of the variance around the mean effect size of ecological processes. Ecology 84, 2335-2346.

Benedetti-Cecchi L, Bertocci I, Vaselli S and Maggi E (2006) Temporal variance reverses the impact of high mean intensity of stress in climate change experiments. Ecology 87, 2489-2499.

Benedetti-Cecchi L, Tamburello L, Maggi E and Bulleri F (2015) Experimental perturbations modify the performance of early warning indicators of regime shift. Current biology 25, 1867-1872.

Benedetti-Cecchi L, Bulleri F, Dal Bello M, Maggi E, Ravaglioli C and Rindi L (2018) Hybrid datasets: integrating observations with experiments in the era of macroecology and big data. Ecology 99, 2654-2666.

Benedetti-Cecchi L, Airoldi L, Bulleri F, Fraschetti S and Terlizzi A (2019) Species interactions and regime shifts in intertidal and subtidal rocky reefs of the Mediterranean Sea. In Hawkins, SJ, Bohn, K, Firth, LB and Williams, GA (eds) Interactions in the marine benthos: Global patterns and processes. Cambridge University Press, pp. 190213.

Bennell SJ (1981) Some observations on the littoral barnacle populations of North Wales. Marine Environmental Research 5, 227-240.

Bennion M, Fisher J, Yesson C and Brodie J (2019) Remote sensing of kelp (Laminariales, Ochrophyta): monitoring tools and implications for wild harvesting. Reviews in Fisheries Science \& Aquaculture 27, 127-141.

Berlow EL (1997) Intertidal ecology. Trends in Ecology \& Evolution 12.

Bertness MD and Shumway SW (1993) Competition and facilitation in marsh plants. The American Naturalist 142, 718-724.

Bertness MD and Callaway R (1994) Positive interactions in communities. Trends in Ecology \& Evolution 9, 191-193.

Bertness MD and Leonard GH (1997) The role of interactions in communities: Lessons from intertidal habitats. Ecology 78, 1976-1989.

Bertness MD, Gaines SD, Bermudez D and Sanford E (1991) Extreme spatial variation in the growth and reproductive output of the acorn barnacle Semibalanus balanoides. Marine Ecology Progress Series 75, 91-100. 
Bertness MD, Leonard GH, Levine JM, Schmidt PR and Ingraham AO (1999) Testing the relative contribution of positive and negative interactions in rocky intertidal communities. Ecology 80, 2711-2726.

Bertness MD, Gaines SD and Hay ME (2001) Marine community ecology, Sinauer Associates Sunderland, MA.

Bertness MD, Trussell GC, Ewanchuk PJ and Silliman BR (2002) Do alternate stable community states exist in the Gulf of Maine rocky intertidal zone? Ecology 83, 34343448.

Bertness MD, Crain CM, Silliman BR, Bazterrica MC, Reyna MV, Hildago F and Farina JK (2006) The community structure of western Atlantic Patagonian rocky shores. Ecological Monographs 76, 439-460.

Bertness MD, Bruno JF, Silliman BR and Stachowicz JJ (2014) Marine community ecology and conservation, Sinauer Associates.

Bertocci I, Maggi E, Vaselli S and Benedetti-Cecchi L (2005) Contrasting effects of mean intensity and temporal variation of disturbance on a rocky seashore. Ecology 86, 20612067.

Bertocci I, Maggi E, Vaselli S and Benedetti-Cecchi L (2010) Resistance of rocky shore assemblages of algae and invertebrates to changes in intensity and temporal variability of aerial exposure. Marine Ecology Progress Series 400, 75-86.

Bishop MJ, Mayer-Pinto M, Airoldi L, Firth LB, Morris RL, Loke LH, Hawkins SJ, Naylor LA, Coleman RA and Chee SY (2017) Effects of ocean sprawl on ecological connectivity: impacts and solutions. Journal of Experimental Marine Biology and Ecology 492, 7-30.

Blamey LK and Branch G (2009) Habitat diversity relative to wave action on rocky shores: implications for the selection of marine protected areas. Aquatic Conservation: Marine and Freshwater Ecosystems 19, 645-657.

Boaden PJ and Dring M (1980) A quantitative evaluation of the effects of Ascophyllum harvesting on the littoral ecosystem. Helgoländer Meeresuntersuchungen 33, 700.

Boaventura D, Alexander M, Santina, PD, Smith ND, Ré P, da Fonseca LC, Hawkins SJ (2002a) The effects of grazing on the distribution and composition of low-shore algal communities on the central coast of Portugal and on the southern coast of Britain. Journal of Experimental Marine Biology and Ecology 267, 1855-206.

Boaventura D, da Fonseca LC, Hawkins SJ (2002b) Analysis of competitive interactions between the limpets Patella depressa Pennant and Patella vulgata L. on the northern coast of Portugal. Journal of Experimental Marine Biology and Ecology 271, 171-188.

Boaventura D, da Fonesca LC, Hawkins SJ (2003) Size matters: competition within populations of the limpet Patella depressa. Journal of Animal Ecology 72, 435-446.

Bodin P and Klinger T (1986) Coastal uplift and mortality of intertidal organisms caused by the September 1985 Mexico earthquakes. Science 233, 1071-1073.

Borges CDG, Hawkins SJ, Doncaster CP and Crowe TP (2015) Effects of simulated human exploitation of a key grazer, Patella vulgata, on rocky shore assemblages. Marine Ecology Progress Series 533, 163-176.

Bosman AL, Du Toit JT, Hockey PA and Branch GM (1986) A field experiment demonstrating the influence of seabird guano on intertidal primary production. Estuarine, Coastal and Shelf Science 23, 283-294.

Boudouresque CF (1971) Contribution a l'etudes phytosociologique des peuplements alguax a la cote varioses. Vegetatio 22, 83-184.

Bowman RS and Lewis J (1977) Annual fluctuations in the recruitment of Patella vulgata L. Journal of the Marine Biological Association of the United Kingdom 57, 793-815.

Branch G (1975) Intraspecific competition in Petella cochlear born. The Journal of Animal Ecology, 263-281.

Branch G (1976) Interspecific competition experienced by South African Patella species. The Journal of Animal Ecology, 507-529.

Branch G (1985) The impact of predation by kelp gulls Larus dominicanus on the subAntarctic limpet Nacella delesserti. Polar Biology 4, 171-177. 
Branch G and Branch M (1981) The living shores of southern Africa, Cape Town: Struik Publishers.

Branch G and Branch M (2018) Living shores - Interacting with southern Africa's marine ecosystems. Cape Town: Struik Nature.

Branch GM, Thompson RC, Crowe TP, Castilla JC, Langmead O and Hawkins SJ (2008) Rocky intertidal shores: prognosis for the future. In Polunin, N. (ed.) Aquatic ecosystems; trends and global prospects. Cambridge University Press, pp. 209-225.

Branch M and Branch G (1986) The living shores of southern Africa, Cape Town: Struik Publishers.

Brodie J, Ash LV, Tittley I and Yesson C (2018) A comparison of multispectral aerial and satellite imagery for mapping intertidal seaweed communities. Aquatic Conservation: Marine and Freshwater Ecosystems 28, 872-881.

Broekhuysen GJ (1940) A preliminary investigation of the importance of desiccation, temperature, and salinity as factors controlling the vertical distribution of certain intertidal marine gastropods in False Bay, South Africa. Transactions of the Royal Society of South Africa 28, 255-292.

Broitman BR, Navarrete SA, Smith F and Gaines SD (2001) Geographic variation of southeastern Pacific intertidal communities. Marine Ecology Progress Series 224, 21 34.

Browne MA and Chapman MG (2011) Ecologically informed engineering reduces loss of intertidal biodiversity on artificial shorelines. Environmental Science \& Technology 45, 8204-8207.

Browne MA and Chapman MG (2014) Mitigating against the loss of species by adding artificial intertidal pools to existing seawalls. Marine Ecology Progress Series 497, 119129.

Bruno JF and O'Connor MI (2005) Cascading effects of predator diversity and omnivory in a marine food web. Ecology Letters 8, 1048-1056.

Bugnot AB, Mayer-Pinto M, Airoldi L, Heery EC, Johnston EL, Critchley LP, Strain EM, Morris RL, Loke LH, Bishop MJ, Sheehan EV, Coleman RA and Dafforn KA (2020) Current and projected global extent of marine built structures. Nature Sustainability https://doi.org/10.1038/s41893-020-00595-1.

Bullard SG, Whitlatch RB and Osman RW (2004) Checking the landing zone: Do invertebrate larvae avoid settling near superior spatial competitors? Marine Ecology Progress Series 280, 239-247.

Bulleri F and Chapman MG (2010) The introduction of coastal infrastructure as a driver of change in marine environments. Journal of Applied Ecology 47, 26-35.

Bulleri F, Eriksson BK, Queirós A, Airoldi L, Arenas F, Arvanitidis C, Bouma TJ, Crowe TP, Davoult D, Guizien K, Iveša L, Jenkins SR, Michalet R, Olabarria C, Procaccini G, Serrão EA, Wahl M and Benedetti-Cecchi L (2018a) Harnessing positive species interactions as a tool against climate-driven loss of coastal biodiversity. PLOS Biology 16, e2006852.

Bulleri F, Cucco A, Dal Bello M, Maggi E, Ravaglioli C and Benedetti-Cecchi L (2018b) The role of wave-exposure and human impacts in regulating the distribution of alternative habitats on NW Mediterranean rocky reefs. Estuarine, Coastal and Shelf Science 201, 114-122.

Burcharth H, Hawkins S, Zanuttigh B and Lamberti (2007) Environmental design guidelines for low crested coastal structures, Oxford: Elsevier.

Burrows EM (1947) A biological study of Ascophyllum nodosum. Ph.D. thesis, London University.

Burrows EM, Lodge S (1950) A note on the interrelationships of Patella, Balanus and Fucus on a semiexposed coast. Reports of the Port Erin Marine Biological Station, 62, 30-34.

Burrows EM and Lodge S (1951) Autecology and the species problem in Fucus. Journal of the Marine Biological Association of the United Kingdom 30, 161-176.

Burrows MT and Hawkins SJ (1998) Modelling patch dynamics on rocky shores using deterministic cellular automata. Marine Ecology Progress Series 167, 1-13. 
Burrows MT, Jenkins SR, Robb L and Harvey R (2010) Spatial variation in size and density of adult and post-settlement Semibalanus balanoides: effects of oceanographic and local conditions. Marine Ecology Progress Series 398, 207-219.

Bustamante R and Branch G (1996) Large scale patterns and trophic structure of southern African rocky shores: the roles of geographic variation and wave exposure. Journal of Biogeography 23, 339-351.

Bustamante R, Branch G and Eekhout S (1995a) Maintenance of an exceptional intertidal grazer biomass in South Africa: subsidy by subtidal kelps. Ecology 76, 2314-2329.

Bustamante RH, Branch GM, Eekhout S, Robertson B, Zoutendyk P, Schleyer M, Dye A, Hanekom N, Keats D and Jurd M (1995b) Gradients of intertidal primary productivity around the coast of South Africa and their relationships with consumer biomass. Oecologia 102, 189-201.

Carpenter SR, Cole JJ, Pace ML, Batt R, Brock W, Cline T, Coloso J, Hodgson JR, Kitchell JF and Seekell DA (2011) Early warnings of regime shifts: a wholeecosystem experiment. Science 332, 1079-1082.

Castilla J and Duran L (1985) Human exclusion from the rocky intertidal zone of central Chile: the effects on Concholepas concholepas (Gastropoda). Oikos, 391-399.

Castilla JC and Paine RT (1987) Predation and community organization on eastern Pacific, temperate zone, rocky intertidal shores. Revista Chilena de Historia Natura 60, 131151.

Castilla JC and Bustamante RH (1989) Human exclusion from rocky intertidal of Las Cruces, Central Chile: effects on Durvillaea antarctica (Phaeophyta, Durvilleales). Marine Ecology Progress Series 50, 203-214.

Castilla JC and Oliva D (1990) Ecological consequences of coseismic uplift on the intertidal kelp belts of Lessonia nigrescens in central Chile. Estuarine, Coastal and Shelf Science 31, 45-56.

Cervin G, Åberg P and Jenkins, SR (2005) Small-scale disturbance in a stable canopy dominated community: implications for macroalgal recruitment and growth. Marine Ecology Progress Series 305, 31-40.

Chan BK, Tsang LM and Chu KH (2007) Cryptic Diversity of the Tetraclita squamosa complex (Crustacea, Cirripedia) in Asia: description of a new species from Singapore. Zoological Studies 46, 46-56.

Chan BK, Kolbasov GA and Cheang CC (2012) Cryptic diversity of the acrothoracican barnacle Armatoglyptes taiwanus in the Indo-Pacific waters, with description of a new species from the Mozambique Channel collected from the MAINBAZA cruise. Zoosystema 34, 5-20.

Chapman ARO (1995) Functional ecology of fucoid algae: twenty-three years of progress. Phycologia 34, 1-32.

Chapman M and Underwood A (1992) Experimental designs for analyses of movements by molluscs. Proceedings of the Third International Symposium on Littorinid Biology. The Malacological Society of London, pp. 169-180.

Chapman MG (1986) Assessment of some controls in experimental transplants of intertidal gastropods. Journal of Experimental Marine Biology and Ecology 103, 181-201.

Chapman MG (2017) Intertidal boulder-fields: a much neglected, but ecologically important, intertidal habitat. Oceanography and Marine Biology: An Annual Review 55, 35-54.

Christofoletti RA, Almeida TV and Ciotti ÁM (2011) Environmental and grazing influence on spatial variability of intertidal biofilm on subtropical rocky shores. Marine Ecology Progress Series 424, 15-23.

Choat JH (1977) The influence of sessile organisms on the population biology of three species of acmaeid limpets. Jounral of Experimental Marine Biology and Ecology 26, 1-26.

Cigliano JA and Ballard HL (2017) Citizen science for coastal and marine conservation, Routledge.

Coleman R and Hockey P (2008) Effects of an alien invertebrate species and wave action on prey selection by African black oystercatchers (Haematopus moquini). Austral Ecology 33, 232-240. 
Coleman RA, Underwood AJ, Benedetti-Cecchi L, Åberg P, Arenas F, Arrontes J, Castro J, Hartnoll RG, Jenkins SR, Paula J, Santina PD and Hawkins SJ (2006) A continental scale evaluation of the role of limpet grazing on rocky shores. Oecologia 147, 556-564.

Coleman RA, Goss-Custard JD, Durell S and Hawkins SJ (1999) Limpet Patella spp. consumption by oystercatchers Haematopus ostralegus: a preference for solitary prey items. Marine Ecology Progress Series 183, 253-261.

Colman $\mathbf{J}$ (1933) The nature of the intertidal zonation of plants and animals. Journal of the Marine Biological Association of the United Kingdom 18, 435-476.

Connell JH (1961a) The influence of interspecific competition and other factors on the distribution of the barnacle Chthamalus stellatus. Ecology 42, 710-723.

Connell JH (1961b) Effects of competition, predation by Thais lapillus, and other factors on natural populations of the barnacle Balanus balanoides. Ecological Monographs 31, 61-104.

Connell JH (1970) A predator-prey system in the marine intertidal region. I. Balanus glandula and several predatory species of Thais. Ecological Monographs 40, 49-78.

Connell JH (1972) Community interactions on marine rocky intertidal shores. Annual Review of Ecology and Systematics 3, 169-192.

Connell JH (1974) Ecology: field experiments in marine ecology. Experimental Marine Biology, 21-54.

Connell JH (1978) Diversity in tropical rain forests and coral reefs. Science 199, 1302-1310.

Connell JH (1985) The consequences of variation in initial settlement vs. post-settlement mortality in rocky intertidal communities. Journal of Experimental Marine Biology and Ecology 93, 11-45.

Connell JH and Slatyer RO (1977) Mechanisms of succession in natural communities and their role in community stability and organization. The American Naturalist 111, 11191144.

Connolly SR and Roughgarden J (1998) A latitudinal gradient in northeast Pacific intertidal community structure: evidence for an oceanographically based synthesis of marine community theory. The American Naturalist 151, 311-326.

Connolly SR, Menge BA and Roughgarden J (2001) A latitudinal gradient in recruitment of intertidal invertebrates in the northeast Pacific Ocean. Ecology 82, 1799-1813.

Conway E (1946) Browsing of Patella. Nature 158, 752-752.

Coombes MA, La Marca EC, Naylor LA and Thompson RC (2015) Getting into the groove: opportunities to enhance the ecological value of hard coastal infrastructure using finescale surface textures. Ecological Engineering 77, 314-323.

Coppejans E (1980) Phytosociological studies on Mediterranean algal vegetation: rocky surfaces of the photophilic infralittoral zone. The Shore Environment 2, 371-393.

Creese R and Underwood A (1982) Analysis of inter-and intra-specific competition amongst intertidal limpets with different methods of feeding. Oecologia 53, 337-346.

Crisp DJ and Knight-Jones EW (1953) The mechanism of aggregation in barnacle populations. Journal of Animal Ecology 22, 360-362.

Crisp DJ and Barnes H (1954) The orientation and distribution of barnacles at settlement with particular reference to surface contour. Journal of Animal Ecology 23, 142-162.

Crowe T, Frost $\mathbf{N}$ and Hawkins $\mathbf{S}$ (2011) Interactive effects of losing key grazers and ecosystem engineers vary with environmental context. Marine Ecology Progress Series 430, 223-234.

Dafforn KA, Glasby TM, Airoldi L, Rivero NK, Mayer-Pinto M and Johnston EL (2015) Marine urbanization: an ecological framework for designing multifunctional artificial structures. Frontiers in Ecology and the Environment 13, 82-90.

Dakin WJ (1953) Australian seashores, Angus \& Robertson.

Dal Bello M, Rindi L and Benedetti-Cecchi L (2017) Legacy effects and memory loss: how contingencies moderate the response of rocky intertidal biofilms to present and past extreme events. Global Change Biology 23, 3259-3268. 
Dando PR and Southward AJ (1980). A new species of Chthamalus (Crustacea: Cirripedia) characterized by enzyme electrophoresis and shell morphology: with a revision of other species of Chthamalus from the western shores of the Atlantic Ocean. Journal of the Marine Biological Association of the United Kingdom 60, 787-831.

Darwin C (1854) A monograph on the sub-class Cirripedia, The Ray Society.

Davies AJ, Johnson MP and Maggs CA (2007) Limpet grazing and loss of Ascophyllum nodosum canopies on decadal time scales. Marine Ecology Progress Series 339, 131141.

Dayton PK (1971) Competition, disturbance, and community organization: The provision and subsequent utilization of space in a rocky intertidal community. Ecological Monographs 41, 351-389.

Dayton PK (1975) Experimental evaluation of ecological dominance in a rocky intertidal algal community. Ecological Monographs 45, 137-159.

Delaney DG, Sperling CD, Adams CS and Leung B (2008) Marine invasive species: validation of citizen science and implications for national monitoring networks. Biological Invasions 10, 117-128.

Dickinson JL, Shirk J, Bonter D, Bonney R, Crain RL, Martin J, Phillips T and Purcell K (2012) The current state of citizen science as a tool for ecological research and public engagement. Frontiers in Ecology and the Environment 10, 291-297.

Doherty P (1981) Coral reef fishes: recruitment limited assemblages? Proceedings of the International Coral Reef Symposium. pp. 465-470.

Doherty PJ and Williams D (1988) The replenishment of coral reef fish populations. Oceanography and Marine Biology: An Annual Review 26, 551.

Doty MS (1946) Critical tide factors that are correlated with the Vertical distribution of marine algae and other organisms along the Pacific coast. Ecology 27, 315-328.

Duarte CM, Pitt KA, Lucas CH, Purcell JE, Uye S-I, Robinson K, Brotz L, Decker MB, Sutherland KR, Malej A, Madin L, Mainzan H, Gili J-M, Fuentes, V, Atienza D, Pages F, Breitburg D, Malek J, Graham WM and Condon RH (2012) Is global ocean sprawl a cause of jellyfish blooms? Frontiers in Ecology and the Environment 11, 9197.

Dudgeon S and Petraitis PS (2005) First year demography of the foundation species, Ascophyllum nodosum, and its community implications. Oikos 109, 405-415.

Dudgeon SR and Petraitis PS (2019) Rocky intertidal shores of the north-west Atlantic ocean. In Hawkins, SJ, Bohn, K, Firth, LB and Williams, GA (eds) Interactions in the marine benthos: Global patterns and processes. Cambridge University Press, pp. 6189.

Dungan ML (1986) Three-way interactions: barnacles, limpets, and algae in a Sonoran Desert rocky intertidal zone. The American Naturalist 127, 292-316.

Easterling DR, Meehl GA, Parmesan C, Changnon SA, Karl TR and Mearns LO (2000) Climate extremes: observations, modeling, and impacts. Science 289, 2068-2074.

Ebling FJ, Sloane JF, Kitching JA and Davies HM (1962) The Ecology of Lough Ine: XII. The distribution and characteristics of Patella species. Journal of Animal Ecology 31, 457-470.

Emmerson MC, Solan M, Emes C, Paterson DM and Raffaelli D (2001) Consistent patterns and the idiosyncratic effects of biodiversity in marine ecosystems. Nature 411, 73-77.

Evans RG (1947) The intertidal ecology of selected localities in the Plymouth neighbourhood. Journal of the Marine Biological Association of the United Kingdom 27, 173-218.

Evans AJ, Firth LB, Hawkins SJ, Morris ES, Goudge H and Moore PJ (2016) Drill-cored rock pools: an effective method of ecological enhancement on artificial structures. Marine and Freshwater Research 67, 123.

Evans AJ, Firth LB, Hawkins SJ, Hall AE, Ironside JE, Thompson RC and Moore PJ (2019) From ocean sprawl to blue-green infrastructure - A UK perspective on an issue of global significance. Environmental Science \& Policy 91, 60-69. 
Fairweather PG (1988) Consequences of supply-side ecology: manipulating the recruitment of intertidal barnacles affects the intensity of predation upon them. The Biological Bulletin 175, 349-354.

Farrell TM (1991) Models and mechanisms of succession: an example from a rocky intertidal community. Ecological Monographs 61, 95-113.

Farrell TM, Bracher D and Roughgarden J (1991) Cross-shelf transport causes recruitment to intertidal populations in central California. Limnology and Oceanography 36, 279288.

Fenberg PB and Menge BA (2019) North-east Pacific: Interactions on intertidal hard substrata and alteration by human impacts. In Hawkins, SJ, Bohn, K, Firth, LB and Williams, GA (eds) Interactions in the marine benthos: Global patterns and processes. Cambridge University Press, pp. 237-259.

Ferreira JG, Arenas F, Martínez B, Hawkins SJ and Jenkins SR (2014) Physiological response of fucoid algae to environmental stress: comparing range centre and southern populations. New Phytologist 202, 1157-1172.

Ferreira JG, Hawkins SJ and Jenkins, SR (2015) Physical and biological control of fucoid recruitment in range edge and range centre populations. Marine Ecology Progress Series 518, 85-94.

Firth LB, Crowe TP, Moore P, Thompson RC and Hawkins SJ (2009) Predicting impacts of climate-induced range expansion: an experimental framework and a test involving key grazers on temperate rocky shores. Global Change Biology 15, 1413-1422.

Firth LB, Thompson RC, White R, Schofield M, Skov MW, Hoggart SPG, Jackson J, Knights AM and Hawkins SJ (2013) Promoting biodiversity on artificial structures: can natural habitats be replicated? Diversity and Distributions 19, 1275-1283.

Firth LB, Thompson RC, Bohn K, Abbiati M, Airoldi L, Bouma TJ, Bozzeda F, Ceccherelli VU, Colangelo MA, Evans A, Ferrario F, Hanley ME, Hinz H, Hoggart SPG, Jackson JE, Moore P, Morgan EH, Perkol-Finkel S, Skov MW, Strain EM, Van Belzen J and Hawkins SJ (2014) Between a rock and a hard place: Environmental and engineering considerations when designing coastal defence structures. Coastal Engineering 87, 122-135.

Firth LB, Mieszkowska N, Grant LM, Bush LE, Davies AJ, Frost MT, Moschella PS, Burrows MT, Cunningham PN, Dye SR and Hawkins SJ (2015) Historical comparisons reveal multiple drivers of decadal change of an ecosystem engineer at the range edge. Ecology and Evolution 5, 3210-3222.

Firth LB, Browne KA, Knights AM, Hawkins SJ and Nash R (2016) Eco-engineered rock pools: a concrete solution to biodiversity loss and urban sprawl in the marine environment. Environmental Research Letters 11, 094015.

Fletcher WJ and Creese RG (1985) Competitive interactions between co-occurring herbivorous gastropods. Marine Biology 86, 183-191.

Foster BA (1971) Desiccation as a factor in the intertidal zonation of barnacles. Marine Biology 8, 12-29.

Fraschetti S, Terlizzi A and Benedetti-Cecchi L (2005) Patterns of distribution of marine assemblages from rocky shores: evidence of relevant scales of variation. Marine Ecology Progress Series 296, 13-29.

Gaines SD and Roughgarden J (1985) Larval settlement rate: A leading determinant of structure in an ecological community of the marine intertidal zone. Proceedings of the National Academy of Sciences 82, pp. 3707.

Gaines SD, Brown S and Roughgarden J (1985) Spatial variation in larval concentrations as a cause of spatial variation in settlement for the barnacle, Balanus glandula. Oecologia 67, 267-272.

Gilfillan ES, Maher NP, Krejsa CM, Lanphear ME, Ball CD, Meltzer JB and Page DS (1995) Use of remote sensing to document changes in marsh vegetation following the Amoco Cadiz oil spill (Brittany, France, 1978). Marine Pollution Bulletin 30, 780-787.

Giller P, Hillebrand H, Berninger UG, Gessner M, Hawkins S, Inchausti P, Inglis C, Leslie H, Malmqvist B and Monaghan M (2004) Biodiversity effects on ecosystem 
functioning: emerging issues and their experimental test in aquatic environments. Oikos 104, 423-436.

Gomes I, Peteiro L, Bueno-Pardo J, Albuquerque R, Pérez-Jorge S, Oliveira ER, Alves FL and Queiroga H (2018) What's a picture really worth? On the use of drone aerial imagery to estimate intertidal rocky shore mussel demographic parameters. Estuarine, Coastal and Shelf Science 213, 185-198.

Gordon JM and Knights AM (2018) Revisiting Connell: competition but not as we know it. Journal of the Marine Biological Association of the United Kingdom 98, 1253-1261.

Gorgula SK and Connell SD (2004) Expansive covers of turf-forming algae on human dominated coast: the relative effects of increasing nutrient and sediment loads. Marine Biology 145, 613-619.

Gosse PH (1856) Tenby: A sea-side holiday, London, John Van Voorst, Paternoster Row.

Gosselin LA and Qian P-Y (1997) Juvenile mortality in benthic marine invertebrates. Marine Ecology Progress Series 146, 265-282.

Griffin JN, De La Haye KL, Hawkins SJ, Thompson RC and Jenkins SR (2008) Predator diversity and ecosystem functioning: density modifies the effect of resource partitioning. Ecology 89, 298-305.

Griffin JN, Noël L, Crowe T, Burrows M, Hawkins SJ, Thompson RC and Jenkins SR (2010) Consumer effects on ecosystem functioning in rock pools: roles of species richness and composition. Marine Ecology Progress Series 420, 45-56.

Grosberg RK (1981) Competitive ability influences habitat choice in marine invertebrates. Nature 290, 700-702.

Guichard F, Bourget E and Agnard JP (2000) High-resolution remote sensing of intertidal ecosystems: A low-cost technique to link scale-dependent patterns and processes. Limnology and Oceanography 45, 328-338.

Guiler ER (1954) The recolonization of rock surfaces and the problem of succession. Papers and Proceedings of the Royal Society of Tasmania. pp. 49-66.

Hamilton DJ, Nudds TD and Neate J (1999) Size-selective predation of blue mussels (Mytilus edulis) by common eiders (Somateria mollissima) under controlled field conditions. The Auk 116, 403-416.

Harasti D, Gallen C, Malcolm H, Tegart P and Hughes B (2014) Where are the little ones: distribution and abundance of the threatened serranid Epinephelus daemelii (Günther, 1876) in intertidal habitats in New South Wales, Australia. Journal of Applied Ichthyology 30, 1007-1015.

Hariot MP (1909) Sur la crissance des Fucus. Comptes Rendus Hebdomadaires des Seances de l'Academie des Sciences Paris 149, 352-354.

Harley CD (2006) Effects of physical ecosystem engineering and herbivory on intertidal community structure. Marine Ecology Progress Series 317, 29-39.

Hartnoll RG and Hawkins SJ (1985) Patchiness and fluctuations on moderately exposed rocky shores. Ophelia 24, 53-63.

Hatton H (1938) Essais de bionomie explicative sur quelques espkces intercotidales d'algues et d'animaux. Annales de l'Institut Océanographique, Monaco 17, 241-348.

Hatton H and Fischer-Piette E (1932) Observations et experiences sur le peuplement des cotes rocheuses par les Cirripedes. Bulletin de I'Institut océanographique, Monaco 592, 15.

Hawkins SJ (1981b) The influence of season and barnacles on the algal colonization of Patella vulgata exclusion areas. Journal of the Marine Biological Association of the United Kingdom 61, 1.

Hawkins SJ (1981a) The influence of Patella grazing on the fucoid-barnacle mosaic on moderately exposed rocky shores. Kieler Meeresforsch 33, 537-543.

Hawkins SJ (1983) Interactions of Patella and macroalgae with settling Semibalanus balanoides (L.). Journal of Experimental Marine Biology and Ecology 71, 55-72.

Hawkins SJ (2004) Scaling up: the role of species and habitat patches in functioning of coastal ecosystems. Aquatic Conservation: Marine and Freshwater Ecosystems 14, 217-219. 
Hawkins SJ and Hartnoll RG (1979) A compressed air drill powered by SCUBA cylinders for use on rocky shores. Estuarine and Coastal Shelf Science 9, 819-820.

Hawkins SJ and Hartnoll RG (1982a) Settlement patterns of Semibalanus balanoides (L.) in the Isle of Man (1977-1981). Journal of Experimental Marine Biology and Ecology 62 , 271-283.

Hawkins SJ and Hartnoll RG (1982b) The influence of barnacle cover on the numbers, growth and behaviour of Patella vulgata on a vertical pier. Journal of the Marine Biological Association of the United Kingdom 62, 855.

Hawkins SJ and Hartnoll RG (1983a) Grazing of intertidal algae by marine invertebrates. Oceanography and Marine Biology: An Annual Review 21, 195-282.

Hawkins SJ and Hartnoll RG (1983b) Changes in a rocky shore community: An evaluation of monitoring. Marine Environmental Research 9, 131-181.

Hawkins SJ \& Hartnoll RG (1985) Factors determining the upper limits of intertidal canopyforming algae. Marine Ecology Progress Series 20, 265-271.

Hawkins SJ and Southward AJ (1992) The Torrey Canyon oil spill: recovery of rocky shore communities. In Thayer GW (ed.) Restoring the nation's marine environment. Maryland: Proceedings of the Symposium on Marine Habitat Restoration. National Oceanic and Atmospheric Administration, Maryland Sea Grant College, Maryland, USA. Sea Grant Publication, pp. 584-631.

Hawkins SJ, Southward AJ and Barrett RL (1983) Population structure of Patella vulgata during succession on rocky shores in South-west England. Oceanologica Acta, Special, 103-107.

Hawkins SJ, Hartnoll RG, Kain JM and Norton TA (1992) Plant-animal interactions on hard substrata in the northeast Atlantic. In John, DM, Hawkins, SJ and Price, JH (eds) Plantanimal interactions in the marine benthos. Oxford University Press, pp. 1-32.

Hawkins SJ, Southward AJ and Genner MJ (2003) Detection of environmental change in a marine ecosystem-evidence from the western English Channel. Science of the Total Environment 310, 245-256.

Hawkins SJ, Hiscock K, Marsterson P and Moore P (2007) Monitoring: Long-term studies. In Denny, MW and Gaines, SD (eds) Encyclopedia of tidepools and rocky shores. University of California Press.

Hawkins SJ, Moore PJ, Burrows MT, Poloczanska E, Mieszkowska N, Herbert RJH, Jenkins, S. R., Thompson RC, Genner MJ and Southward AJ (2008) Complex interactions in a rapidly changing world: responses of rocky shore communities to recent climate change. Climate Research 37, 123-133.

Hawkins SJ, Sugden HE, Mieszkowska N, Moore PJ, Poloczanska E, Leaper R, Herbert RJH, Genner MJ, Moschella PS, Thompson RC, Jenkins SR, Southward AJ and Burrows MT (2009) Consequences of climate-driven biodiversity changes for ecosystem functioning of North European rocky shores. Marine Ecology Progress Series 396, 245-259.

Hawkins SJ, Bohn K and Doncaster CP (2015) Ecosystems: The rocky road to regime-shift indicators. Current Biology 25, R666-R669.

Hawkins SJ, Mieszkowska N, Firth LB, Bohn K, Burrows MT, Maclean MA, Thompson RC, Chan BKK, Little C and Williams GA (2016) Looking backwards to look forwards: the role of natural history in temperate reef ecology. Marine and Freshwater Research 67, 1-13.

Hawkins SJ, Evans AJ, Mieszkowska N, Adams LC, Bray S, Burrows MT, Firth LB, Genner MJ, Leung KMY, Moore PJ, Pack K, Schuster H, Sims DW, Whittington M and Southward EC (2017a) Distinguishing globally-driven changes from regional- and local-scale impacts: The case for long-term and broad-scale studies of recovery from pollution. Marine Pollution Bulletin.

Hawkins SJ, Evans AJ, Moore J, Whittington M, Pack K, Firth LB, Adams LC, Moore PJ, Masterson-Algar P, Mieszkowska N and Southward EC (2017b) From the Torrey Canyon to today: A 50 year retrospective of recovery from the oil spill and interaction 
with climate-driven fluctuations on cornish rocky shores. International Oil Spill Conference Proceedings. pp. 74-103.

Hawkins SJ, Bohn K, Firth LB and Williams GA (2019a) Interactions in the marine benthos: Global patterns and processes, Cambridge, Cambridge University Press.

Hawkins SJ, Bohn K, Lemasson AJ, Williams GA, Schiel DR, Jenkins SR and Firth LB (2019c) Overview and Synthesis. In Hawkins, SJ, Bohn, K, Firth, LB and Williams, GA (eds) Interactions in the marine benthos: Global patterns and processes. Cambridge University Press, pp. 488-505.

Hawkins SJ, Pack KE, Firth LB, Mieszkowska N, Evans AJ, Martins GM, Åberg P, Adams LC, Arenas F, Boaventura DM, Bohn K, Borges CDG, Castro JJ, Coleman RA, Crowe TP, Cruz T, Davies MS, Epstein G, Faria J, Ferreira JG, Frost NJ, Griffin JN, Hanley ME, Herbert RJH, Hyder K, Johnson MP, Lima FP, Masterson-Algar P, Moore PJ, Moschella PS, Notman GM, Pannacciulli FG, Ribeiro PA, Santos AM, Silva ACF, Skov MW, Sugden H, Vale M, Wangkulangkul K, Wort EJG, Thompson RC, Hartnoll RG, Burrows MT and Jenkins SR (2019b) The intertidal zone of the north-east Atlantic region: pattern and process. In Hawkins, SJ, Bohn, K, Firth, LB and Williams, GA (eds) Interactions in the Marine Benthos: Global Patterns and Processes. Cambridge University Press, pp. 7-46.

Hawkins SJ, Firth LB and Evans AJ (2020) Structures spread across our seas. Nature Sustainability https://doi.org/10.1038/s41893-020-00598-y.

Hector A, Schmid B, Beierkuhnlein C, Caldeira M, Diemer M, Dimitrakopoulos P, Finn J, Freitas H, Giller P and Good J (1999) Plant diversity and productivity experiments in European grasslands. Science 286, 1123-1127.

Heery EC, Bishop MJ, Critchley LP, Bugnot AB, Airoldi L, Mayer-Pinto M, Sheehan EV, Coleman RA, Loke LH and Johnston EL (2017) Identifying the consequences of ocean sprawl for sedimentary habitats. Journal of Experimental Marine Biology and Ecology 492, 31-48.

Hill AS and Hawkins SJ (1990) An investigation of methods for sampling microbial films on rocky shores. Journal of the Marine Biological Association of the United Kingdom 70, 77-88.

Hill AS and Hawkins SJ (1991) Seasonal and spatial variation of epilithic microalgae distribution and abundance and its ingestion by Patella vulgata on a moderately exposed rocky shore. Journal of the Marine Biological Association of the United Kingdom 71, 403-423.

Hockey P and Underhill L (1984) Diet of the African black oystercatcher Haematopus moquini on rocky shores: spatial, temporal and sex-related variation. African Zoology 19, 1-11.

Holm ER (1990) Effects of density-dependent mortality on the relationship between recruitment and larval settlement. Marine Ecology Progress Series 60, 141-146.

Hughes RN, Hughes DJ and Smith IP (2014) Citizen scientists and marine research: volunteer participants, their contributions, and projection for the future. Oceanography and Marine Biology: An Annual Review 52, 257-314.

Hughes TP, Baird AH, Dinsdale EA, Moltschaniwskyj NA, Pratchett MS, Tanner JE and Willis BL (1999) Patterns of recruitment and abundance of corals along the Great Barrier Reef. Nature 397, 59-63.

Hunt HL and Scheibling RE (1996) Physical and biological factors influencing mussel (Mytilus trossulus, M. edulis) settlement on a wave-exposed rocky shore. Marine Ecology Progress Series 142, 135-145.

Hurlbert SH (1984) Pseudoreplication and the design of ecological field experiments. Ecological Monographs 54, 187-211.

Hyder K, Johnson MP, Hawkins SJ and Gurney WSC (1998) Barnacle demography: Evidence for an existing model and spatial scales of variation. Marine Ecology Progress Series 174, 88-99.

Hyder K, Áberg P, Johnson MP and Hawkins SJ (2001) Models of open populations with space-limited recruitment: extension of theory and application to the barnacle 
Chthamalus montagui: Modelling barnacle populations. Journal of Animal Ecology 70 , 853-863.

Hyder K, Townhill B, Anderson LG, Delany J and Pinnegar JK (2015) Can citizen science contribute to the evidence-base that underpins marine policy? Marine Policy 59, 112 120.

Ingólfsson A and Hawkins SJ (2008) Slow recovery from disturbance: a 20 year study of Ascophyllum canopy clearances. Journal of the Marine Biological Association of the United Kingdom 88.

Jenkins SR (2005) Larval habitat selection, not larval supply, determines settlement patterns and adult distribution in two chthamalid barnacles. Journal of Animal Ecology 74, 893904.

Jenkins SR and Uyà M (2016) Temporal scale of field experiments in benthic ecology. Marine Ecology Progress Series 547, 273-286.

Jenkins SR, Norton TA and Hawkins SJ (1999a) Settlement and post-settlement interactions between Semibalanus balanoides (L.) (Crustacea: Cirripedia) and three species of fucoid canopy algae. Journal of Experimental Marine Biology and Ecology 236, 49-67.

Jenkins SR, Hawkins SJ and Norton TA (1999b) Direct and indirect effects of a macroalgal canopy and limpet grazing in structuring a sheltered inter-tidal community. Marine Ecology Progress Series 188, 81-92.

Jenkins SR, Hawkins SJ and Norton TA (1999c) Interaction between a fucoid canopy and limpet grazing in structuring a low shore intertidal community. Journal of Experimental Marine Biology and Ecology 233, 41-63.

Jenkins SR, Åberg P, Cervin G, Coleman RA, Delany J, Della Santina P, Hawkins SJ, Lacroix E, Myers AA, Lindegarth M, Power AM, Roberts MF and Hartnoll RG (2000) Spatial and temporal variation in settlement and recruitment of the intertidal barnacle Semibalanus balanoides (L.) (Crustacea: Cirripedia) over a European scale. Journal of Experimental Marine Biology and Ecology 243, 209-225.

Jenkins SR, Åberg P, Cervin G, Coleman R, Delany J, Hawkins S, Hyder K, Myers A, Paula J and Power A-M (2001) Population dynamics of the intertidal barnacle Semibalanus balanoides at three European locations: spatial scales of variability. Marine Ecology Progress Series 217, 207-217.

Jenkins SR, Norton TA and Hawkins SJ (2004) Long term effects of Ascophyllum nodosum canopy removal on mid shore community structure. Journal of the Marine Biological Association of the United Kingdom 84, 327-329.

Jenkins SR, Coleman RA, Santina PD, Hawkins SJ, Burrows MT and Hartnoll RG (2005) Regional scale differences in the determinism of grazing effects in the rocky intertidal. Marine Ecology Progress Series 287, 77-86.

Jenkins SR, Moore P, Burrows MT, Garbary DJ, Hawkins SJ, Ingólfsson A, Sebens KP, Snelgrove PVR, Wethey DS and Woodin SA (2008a) Comparative ecology of north Atlantic shores: do differences in players matter for process? Ecology 89, S3-S23.

Jenkins SR, Murua J and Burrows MT (2008b) Temporal changes in the strength of densitydependent mortality and growth in intertidal barnacles. Journal of Animal Ecology 77, 573-584.

John DM, Price JH and Lawson G (1992) Tropical east Atlantic and Islands: plant-animal interactions on tropical shores free of biotic reefs. In John, DM, Hawkins, SJ and Price, $\mathrm{JH}$ (eds) Plant-animal interactions in the marine benthos. Oxford: Clarendon Press, pp. 87-99.

Johnson MP, Burrows M, Hartnoll R and Hawkins SJ (1997) Spatial structure on moderately exposed rocky shores:patch scales and the interactions between limpets and algae. Marine Ecology Progress Series 160, 209-215.

Johnson MP, Burrows M and Hawkins SJ (1998a) Individual based simulations of the direct and indirect effects of limpets on a rocky shore Fucus mosaic. Marine Ecology Progress Series 169, 179-188. 
Johnson MP, Hughes RN, Burrows MT and Hawkins SJ (1998b) Beyond the predation halo: small scale gradients in barnacle populations affected by the relative refuge value of crevices. Journal of Experimental Marine Biology and Ecology 231, 163-170.

Johnson MP, Hawkins SJ, Hartnoll RG and Norton TA (1998c) The establishment of fucoid zontation on algal-dominated rocky shores: hypotheses derived from a simulation model. Marine Ecology Progress Series 169, 179-188.

Johnson MP, Frost NJ, Mosley MWJ, Roberts MF and Hawkins SJ (2003) The areaindependent effects of habitat complexity on biodiversity vary between regions. Ecology Letters 6, 126-132.

Johnson MP, Edwards M, Bunker F and Maggs CA (2005) Algal epiphytes of Zostera marina: Variation in assemblage structure from individual leaves to regional scale. Aquatic Botany 82, 12-26.

Jones NS (1946) Browsing of Patella. Nature 158, 557-558.

Jones NS (1948) Observations and experiments on the biology of Patella vulgata at Port St. Mary, Isle of Man. Proceedings and Transactions of the Liverpool Biological Society. pp. 60-77.

Jones NS and Kain JM (1967) Subtidal algal colonization following the removal of Echinus. Helgoländer Wissenschaftliche Meeresuntersuchungen 15, 460-466.

Jonsson PR, Granhag L, Moschella PS, Åberg P, Hawkins SJ and Thompson RC (2006) Interactions between wave action and grazing control the distribution of intertidal macroalgae. Ecology 87, 1169-1178.

Keith SA, Herbert RJH, Norton PA, Hawkins SJ and Newton AC (2011) Individualistic species limitations of climate-induced range expansions generated by meso-scale dispersal barriers: Dispersal barriers limit range expansions. Diversity and Distributions 17, 275-286.

Kent A, Hawkins SJ and Doncaster CP (2003) Population consequences of mutual attraction between settling and adult barnacles. Journal of Animal Ecology 72, 941952.

Kingsley C (1859) Glaucus; or, the wonders of the shore, London: Macmillan and Co.

Kitching JA and Ebling FJ (1961) The ecology of Lough Ine. Journal of Animal Ecology 30, 373-383.

Kitching JA, Sloane JF and Ebling FJ (1959) The ecology of Lough Ine: VIII. Mussels and their predators. Journal of Animal Ecology 28, 331-341.

Knight-Jones EW (1951) Gregariousness and some other aspects of the setting behaviour of Sipirorbis. Journal of the Marine Biological Association of the United Kingdom 30, 201-222.

Knight-Jones EW (1953) Laboratory experiments on gregariousness during setting in Balanus balanoides and other barnacles. Journal of Experimental Biology 30, 584-598.

Lebednik PA (1973) Ecological effects of intertidal uplifting from nuclear testing. Marine Biology 20, 197-207.

Leonard GH, Levine JM, Schmidt PR and Bertness MD (1998) Flow-driven variation in intertidal community structure in a Maine estuary. Ecology 79, 1395-1411.

Lewin R (1986) Supply-side ecology. Science 234, 25.

Lewis JR (1964) The ecology of the rocky shores, London, English Universities Press.

Lewis JR (1976a) Long-term ecological surveillance: practical realities in the rocky littoral. Oceanography and Marine Biology: An Annual Review 14, 371-390.

Lewis JR (1976b) Long-term ecological surveillance: practical realities in the rocky littoral Oceanography and Marine Biology: An Annual Review 14, 371-390.

Lewis $\mathbf{J}$ and Bowman RS (1975) Local habitat-induced variations in the population dynamics of Patella vulgata L. Journal of Experimental Marine Biology and Ecology 17, 165-203.

Lima FP and Wethey DS (2009) Robolimpets: measuring intertidal body temperatures using biomimetic loggers. Limnology and Oceanography: Methods 7, 347-353.

Ling SD, Johnson CR, Frusher SD and Ridgway KR (2009) Overfishing reduces resilience of kelp beds to climate-driven catastrophic phase shift. Proceedings of the National Academy of Sciences 106, 22341-22345. 
Lodge SM (1948) Algal growth in the absence of Patella on an experimental strip of foreshore, Port St Mary, Isle of Man. Proceedings and Transactions of the Liverpool Biological Society. pp. 78-85.

Loke LH and Todd PA (2016) Structural complexity and component type increase intertidal biodiversity independently of area. Ecology 97, 383-393.

Loke LH, Jachowski NR, Bouma TJ, Ladle RJ and Todd PA (2014) Complexity for Artificial Substrates (CASU): software for creating and visualising habitat complexity. PLoS One 9, e87990.

Loke LH, Liao LM, Bouma TJ and Todd PA (2016) Succession of seawall algal communities on artificial substrates. Raffles Bulletin of Zoology.

Loke LHL, Ladle RJ, Bouma TJ and Todd PA (2015) Creating complex habitats for restoration and reconciliation. Ecological Engineering 77, 307-313.

Loreau M, Naeem S, Inchausti P, Bengtsson J, Grime J, Hector A, Hooper D, Huston M, Raffaelli D and Schmid B (2001) Biodiversity and ecosystem functioning: current knowledge and future challenges. Science 294, 804-808.

Loreau M, Naeem S and Inchausti P (2002) Biodiversity and ecosystem functioning: synthesis and perspectives, Oxford University Press.

Lubchenco $\mathbf{J}$ (1978) Plant species diversity in a marine intertidal community: importance of herbivore food preference and algal competitive abilities. The American Naturalist 112 , 23-39.

Lubchenco $\mathbf{J}$ (1980) Algal zonation in the New England rocky intertidal community: an experimental analysis. Ecology 61, 333-344.

Lubchenco J (1983) Littornia and Fucus: Effects of herbivores, substratum heterogeneity, and plant escapes during succession. Ecology 64, 1116-1123.

Lubchenco $\mathbf{J}$ and Menge BA (1978) Community development and persistence in a low rocky intertidal zone. Ecological Monographs 48, 67-94.

Luckens PA (1970) Breeding, settlement and survival of barnacles at artificially modified shore levels in Leigh, New Zealand. New Zealand Journal of Marine and Freshwater Research 4, 497-514.

Luckens PA (1975a) Competition and intertidal zonation of barnacles at Leigh, New Zealand. New Zealand Journal of Marine and Freshwater Research 9, 379-394.

Luckens PA (1975b) Predation and intertidal zonation of barnacles at Leigh, New Zealand. New Zealand Journal of Marine and Freshwater Research 9, 355-378.

Maggi E, Bulleri F, Bertocci I and Benedetti-Cecchi L (2012) Competitive ability of macroalgal canopies overwhelms the effects of variable regimes of disturbance. Marine Ecology Progress Series 465, 99-109.

Marshall PA and Keough MJ (1994) Asymmetry in intraspecific competition in the limpet Cellana tramoserica (Sowerby). Journal of Experimental Marine Biology and Ecology 177, 121-38.

Martin D, Bertasi F, Colangelo MA, De Vries M, Frost M, Hawkins SJ, Macpherson E, Moschella PS, Satta MP and Thompson RC (2005) Ecological impact of coastal defence structures on sediment and mobile fauna: evaluating and forecasting consequences of unavoidable modifications of native habitats. Coastal Engineering 52, 1027-1051.

Martins GM, Hawkins SJ, Thompson RC and Jenkins SR (2007) Community structure and functioning in intertidal rock pools: effects of pool size and shore height at different successional stages. Marine Ecology Progress Series 329, 43-55.

Martins GM, Neto Al, Thompson RC, Hawkins SJ and Jenkins SR (2008) Rocky intertidal community structure in oceanic islands: scales of spatial variability. Marine Ecology Progress Series 356, 15-24.

Martins GM, Harley CD, Faria J, Vale M, Hawkins SJ, Neto Al and Arenas F (2019) Direct and indirect effects of climate change squeeze the local distribution of a habitat-forming seaweed. Marine Ecology Progress Series 626, 43-52.

Masterson P, Arenas FA, Thompson RC and Jenkins SR (2008) Interaction of top down and bottom up factors in intertidal rockpools: effects on early successional macroalgal 
community composition, abundance and productivity. Journal of Experimental Marine Biology and Ecology 363, 12-20.

May V, Bennett I and Thompson TE (1970) Herbivore-algal relationships on a coastal rock platform (Cape Banks, N.S.W.). Oecologia 6, 1-14.

McQuaid CD and Blamey LK (2019) Where three oceans meet: state of the art and developments in southern African coastal marine biology. In Hawkins, SJ, Bohn, K, Firth, LB and Williams, GA (eds) Interactions in the marine benthos: Global patterns and processes. Cambridge University Press, pp. 333-359.

McQuaid CD and Lawrie SM (2005) Supply-side ecology of the brown mussel, Perna perna: an investigation of spatial and temporal variation in, and coupling between, gamete release and larval supply. Marine Biology 147, 955-963.

McQuaid CD, Lindsay TL (2000) Effect of wave exposure on growth and mortality rates of the mussel Perna perna: bottom up regulation of intertidal populations. Marine Ecology Progress Series 206, 147-54.

McQuaid CD and Phillips TE (2000) Limited wind-driven dispersal of intertidal mussel larvae: in situ evidence from the plankton and the spread of the invasive species Mytilus galloprovincialis in South Africa. Marine Ecology Progress Series 201, 211-220.

Menconi M, Benedetti-Cecchi L and Cinelli F (1999) Spatial and temporal variability in the distribution of algae and invertebrates on rocky shores in the northwest Mediterranean. Journal of Experimental Marine Biology and Ecology 233, 1-23.

Menge BA (1976) Organization of the New England rocky intertidal community: Role of predation, competition and environmental heterogeneity. Ecological Monographs 46, 355-393.

Menge BA (1983) Components of predation intensity in the low zone of the New England rocky intertidal region. Oecologia 58, 141-155.

Menge BA (1991) Relative importance of recruitment and other causes of variation in rocky intertidal community structure. Journal of Experimental Marine Biology and Ecology 146, 69-100.

Menge BA (1995) Indirect effects in marine rocky intertidal interaction webs: patterns and importance. Ecological monographs 65, 21-74.

Menge BA (2000a) Recruitment vs. postrecruitment processes as determinants of barnacle population abundance. Ecological Monographs 70, 265-288.

Menge BA (2000b) Top-down and bottom-up community regulation in marine rocky intertidal habitats. Journal of Experimental Marine Biology and Ecology 250, 257-289.

Menge B A and Branch GM (2001) Rocky intertidal communities. In Bertness MD, Gaines SD and Hay ME (eds), Marine community ecology. Sunderland: Sinauer Associates, pp. 221-251.

Menge BA and Sutherland JP (1976) Species diversity gradients: synthesis of the roles of predation, competition, and temporal heterogeneity. The American Naturalist 110, 351369.

Menge BA and Sutherland JP (1987) Community regulation: variation in disturbance, competition, and predation in relation to environmental stress and recruitment. The American Naturalist 130, 730-757.

Menge BA and Menge DN (2013) Dynamics of coastal meta-ecosystems: the intermittent upwelling hypothesis and a test in rocky intertidal regions. Ecological Monographs 83, 283-310.

Menge BA, Daley BA, Lubchenco J, Sanford E, Dahlhoff E, Halpin PM, Hudson G and Burnaford JL (1999) Top-down and bottom-up regulation of New Zealand rocky intertidal communities. Ecological Monographs 69, 297-330.

Menge BA, Bracken MES, Lubchenco J and Leslie HM (2017) Alternative state? Experimentally induced Fucus canopy persists $38 \mathrm{yr}$ in an Ascophyllum-dominated community. Ecosphere 8, e01725.

Mieszkowska N, Kendall MA, Hawkins SJ, Leaper R, Williamson P, Hardman-Mountford NJ and Southward AJ (2006) Changes in the range of some common rocky shore species in Britain - a response to climate change? Hydrobiologia 555, 241-251. 
Mieszkowska N, Burrows MT, Pannacciulli FG and Hawkins SJ (2017) Multidecadal signals within co-occurring intertidal barnacles Semibalanus balanoides and Chthamalus spp. linked to the Atlantic Multidecadal Oscillation. Journal of Marine Systems 133, 70-6.

Mills LS, Soulé ME and Doak DF (1993) The keystone-species concept in ecology and conservation. BioScience 43, 219-224.

Minchinton TE (1997) Life on the edge: conspecific attraction and recruitment of populations to disturbed habitats. Oecologia 111, 45-52.

Mishra DR, Cho HJ, Ghosh S, Fox A, Downs C, Merani PBT, Kirui P, Jackson N and Mishra S (2012) Post-spill state of the marsh: Remote estimation of the ecological impact of the Gulf of Mexico oil spill on Louisiana salt marshes. Remote Sensing of Environment 118, 176-185.

Moore P, Hawkins SJ and Thompson RC (2007) Role of biological habitat amelioration in altering the relative responses of congeneric species to climate change. Marine Ecology Progress Series 334, 11-19.

Moreno CA and Jaramillo E (1983) The role of grazers in the zonation of intertidal macroalgae of the Chilean coast. Oikos, 73-76.

Morris RL, Chapman MG, Firth LB and Coleman RA (2017) Increasing habitat complexity on seawalls: Investigating large-and small-scale effects on fish assemblages. Ecology and Evolution 7, 9567-9579.

Morris RL, Heery EC, Loke LH, Lau E, Strain E, Airoldi L, Alexander KA, Bishop MJ, Coleman RA and Cordell JR (2019) Design options, implementation issues and evaluating success of ecologically engineered shorelines. Oceanography and Marine Biology: An Annual Review 57.

Morton B and Morton J (1983) The sea shore ecology of Hong Kong, Cambridge University Press.

Morton B, De Frias Martins AM and Britton JC (1998) Coastal ecology of the Açores, Ponta Delgada, Sociedade Afonso Chaves.

Morton J and Miller M (1968) The New Zealand sea shore, Collins.

Moschella PS, Abbiati M, Åberg P, Airoldi L, Anderson JM, Bacchiocchi F, Bulleri F, Dinesen GE, Frost M, Gacia E, Granhag L, Jonsson PR, Satta MP, Sundelöf A, Thompson RC and Hawkins SJ (2005) Low-crested coastal defence structures as artificial habitats for marine life: Using ecological criteria in design. Coastal Engineering 52, 1053-1071.

Moss B, Mcgowan S and Carvalho L (1994) Determination of phytoplankton crops by topdown and bottom-up mechanisms in a group of English lakes, the West Midland meres. Limnology and Oceanography 39, 1020-1029.

Moyse J and Nelson-Smith A (1963) Zonation of animals and plants on rocky shores around Dale, Pembrokeshire. Field Studies 1, 1-31.

Mrowicki RJ and O'Connor NE (2015) Wave action modifies the effects of consumer diversity and warming on algal assemblages. Ecology 96, 1020-1029.

Mrowicki RJ, Maggs CA and O'Connor NE (2015) Consistent effects of consumer species loss across different habitats. Oikos 124, 1555-1563.

Mumby PJ, Vitolo R and Stephenson DB (2011) Temporal clustering of tropical cyclones and its ecosystem impacts. Proceedings of the National Academy of Sciences 108, 17626-17630.

Murphy R, Underwood A, Pinkerton M and Range P (2005) Field spectrometry: new methods to investigate epilithic micro-algae on rocky shores. Journal of Experimental Marine Biology and Ecology 325, 111-124.

Murphy RJ, Underwood A and Pinkerton MH (2006) Quantitative imaging to measure photosynthetic biomass on an intertidal rock-platform. Marine Ecology Progress Series 312, 45-55.

Nagarkar S and Williams GA (1997) Comparative techniques to quantify cyanobacteria dominated epilithic biofilms on tropical rocky shores. Marine Ecology Progress Series 154, 281-291. 
Nelson-Smith A (1968) The effects of oil pollution and emulsifier cleansing on shore life in south-west Britain. Journal of Applied Ecology 5, 97-107.

Newman G, Wiggins A, Crall A, Graham E, Newman S and Crowston K (2012) The future of citizen science: emerging technologies and shifting paradigms. Frontiers in Ecology and the Environment 10, 298-304.

Noël LMLJ, Hawkins SJ, Jenkins SR and Thompson RC (2009) Grazing dynamics in intertidal rockpools: Connectivity of microhabitats. Journal of Experimental Marine Biology and Ecology 370, 9-17.

Notman G, Mcgill R, Hawkins S and Burrows M (2016) Macroalgae contribute to the diet of Patella vulgata from contrasting conditions of latitude and wave exposure in the UK. Marine Ecology Progress Series 549, 113-123.

O'Connor NE and Crowe TP (2005) Biodiversity loss and ecosystem functioning: distinguishing between number and identity of species. Ecology 86, 1783-1796.

O'Connor NE and Donohue I (2013) Environmental context determines multi-trophic effects of consumer species loss. Global Change Biology 19, 431-440.

O'Connor NE, Emmerson MC, Crowe TP and Donohue I (2013) Distinguishing between direct and indirect effects of predators in complex ecosystems. Journal of Animal Ecology 82, 438-448.

O'Connor NE, Bracken ME, Crowe TP and Donohue I. (2015) Nutrient enrichment alters the consequences of species loss. Journal of Ecology 103, 862-870.

O'Riordan RM and Murphy O (2000) Variation in the reproductive cycle of Elminius modestus in southern Ireland. Journal of the Marine Biological Association of the United Kingdom 80, 607-616.

O'Riordan RM, Arenas F, Arrontes J, Castro JJ, Cruz T, Delany J, Martinez B, Fernandez C, Hawkins, SJ, McGrath D, Myers AA, Oliveros J, Pannacciulli FG, Power A-M, Relini G, Rico JM and Silva, T (2004) Spatial variation in the recruitment of the intertidal barnacles Chthamalus montagui Southward and Chthamalus stellatus (Poli) (crustacean: Cirripedia) over a European scale. Journal of Experimental Marine Biology and Ecology 304, 243-264.

O’Shaughnessy KA, Hawkins SJ, Evans AJ, Hanley ME, Lunt P, Thompson RC, Francis RA, Hoggart SP, Moore PJ and Iglesias G (2019) Design catalogue for ecoengineering of coastal artificial structures: a multifunctional approach for stakeholders and end-users. Urban Ecosystems, 1-13.

Oliver EC, Donat MG, Burrows MT, Moore PJ, Smale DA, Alexander LV, Benthuysen JA, Feng M, Gupta AS and Hobday AJ (2018) Longer and more frequent marine heatwaves over the past century. Nature Communications 9, 1-12.

Ortega S (1985) Competitive interactions among tropical intertidal limpets. Journal of Experimental Marine Biology and Ecology 90, 11-25.

Paine R (1966) Food web complexity and species diversity. The American Naturalist 100, 6575.

Paine R (1969) The Pisaster-Tegula interaction: prey patches, predator food preference, and intertidal community structure. Ecology 50, 950-961.

Paine R (1971) A short-term experimental investigation of resource partitioning in a New Zealand rocky intertidal habitat. Ecology 52, 1096-1106.

Paine R (1974) Intertidal community structure. Oecologia 15, 93-120.

Paine R (1994) Marine rocky shores and community ecology: an experimentalist's perspective, Germany, Ecology Institute Oldendorf/Luhe.

Paine R and Vadas R (1969) The effects of grazing by sea urchins, Strongylocentrotus spp. on benthic algal populations. Limnology and Oceanography 14, 710-719.

Paine R, Castillo JC and Cancino J (1985) Perturbation and recovery patterns of starfishdominated intertidal assemblages in Chile, New Zealand, and Washington State. The American Naturalist 125, 679-691.

Palomo MG, Bagur M, Calla S, Dalton MC, Soria SA and Hawkins SJ (2019) Biodiversity and interactions on the intertidal rocky shores of the Argentina (south-west Atlantic). 
In Hawkins, SJ, Bohn, K, Firth, LB and Williams, GA (eds) Interactions in the marine benthos: Global patterns and processes. Cambridge University Press, pp. 164-189.

Pannacciulli FG, Bishop JD and Hawkins SJ (1997) Genetic structure of populations of two species of Chthamalus (Crustacea: Cirripedia) in the north-east Atlantic and Mediterranean. Marine Biology 128, 73-82.

Peterson BJ and Heck KL (2001) Positive interactions between suspension-feeding bivalves and seagrass a facultative mutualism. Marine Ecology Progress Series 213, 143-155.

Petraitis PS and Dudgeon SR (1999) Experimental evidence for the origin of alternative communities on rocky intertidal shores. Oikos 84, 239-245.

Petraitis PS and Dudgeon SR (2015) Variation in recruitment and the establishment of alternative community states. Ecology 96, 3186-3196.

Pfaff MC, Branch GM, Wieters EA, Branch RA and Broitman BR (2011) Upwelling intensity and wave exposure determine recruitment of intertidal mussels and barnacles in the Southern Benguela upwelling region. Marine Ecology Progress Series 425,141-152.

Pineda J (1991) Predictable upwelling and the shoreward transport of planktonic larvae by internal tidal bores. Science 253, 548.

Pinn EH, Thompson R and Hawkins S (2008) Piddocks (Mollusca: Bivalvia: Pholadidae) increase topographical complexity and species diversity in the intertidal. Marine Ecology Progress Series 355, 173-182.

Pocklington JB, Jenkins SR, Bellgrove A, Keough MJ, O'hara TD, Masterson-Algar PE and Hawkins SJ (2017) Disturbance alters ecosystem engineering by a canopyforming alga. Journal of the Marine Biological Association of the United Kingdom, 112.

Poloczanska ES, Hawkins SJ, Southward AJ and Burrows MT (2008) Modeling the response of populations of competing species to climate change. Ecology 89, 31383149.

Possingham HP and Roughgarden J (1990) Spatial Population Dynamics of a Marine Organism with a Complex Life Cycle: Ecological Archives E071-001. Ecology 71, 973985.

Possingham HP, Tuljapurkar S, Roughgarden J and Wilks M (1994) Population cycling in space-limited organisms subject to density-dependent predation. The American Naturalist 143, 563-582.

Power ME, Tilman D, Estes JA, Menge BA, Bond WJ, Mills LS, Daily G, Castilla JC, Lubchenco J and Paine RT (1996) Challenges in the quest for keystones: identifying keystone species is difficult-but essential to understanding how loss of species will affect ecosystems. BioScience 46, 609-620.

Qian P-Y, Lau SC, Dahms H-U, Dobretsov S and Harder T (2007) Marine biofilms as mediators of colonization by marine macroorganisms: implications for antifouling and aquaculture. Marine Biotechnology 9, 399-410.

R Core Team (2019) R: A language and environment for statistical computing, Vienna, $\mathrm{R}$ Foundation for Statistical Computing.

Raffaelli D and Hawkins S (1996) Intertidal Ecology, Dordrecht: Springer Netherlands.

Reddin CJ, Docmac F, O'Connor NE, Bothwell JH and Harrod C (2015) Coastal upwelling drives intertidal assemblage structure and trophic ecology. PLOS ONE 10, e0130789.

Reed DC and Foster MS (1984) The effects of canopy shadings on algal recruitment and growth in a giant kelp forest. Ecology 65, 937-948.

Renouf $L$ and Rees T (1932) A note on experiments concerned with biotic factors of the seashore. Annals of Botany, 1061-1062.

Ricketts EF and Calvin J (1968) Between Pacific tides, Stanford University Press.

Rilov G, Dudas S, Menge B, Grantham B, Lubchenco J and Schiel D (2008) The surf zone: A semipermeable barrier to onshore recruitment of invertebrate larvae? Journal of Experimental Marine Biology and Ecology, 361, 59-74. 
Rindi L, Dal Bello M, Dai L, Gore J and Benedetti-Cecchi L (2017) Direct observation of increasing recovery length before collapse of a marine benthic ecosystem. Nature Ecology \& Evolution 1, 1-7.

Rittschof D, Branscomb ES and Costlow JD (1984) Settlement and behavior in relation to flow and surface in larval barnacles, Balanus amphitrite Darwin. Journal of Experimental Marine Biology and Ecology 82, 131-146.

Rosenthal IS, Byrnes JE, Cavanaugh KC, Bell TW, Harder B, Haupt AJ, Rassweiler AT, Pérez-Matus A, Assis J and Swanson A (2018) Floating Forests: Quantitative validation of citizen science data generated from consensus classifications. arXiv Preprint, 1801.08522.

Roughgarden J, Iwasa Y and Baxter C (1985) Demographic theory for an open marine population with space-limited recruitment. Ecology 66, 54-67.

Roughgarden J, Gaines S and Pacala S (1987) Published. Supply side ecology: the role of physical transport processes. Symposium of the British Ecological Society.

Roughgarden J, Gaines S and Possingham H (1988) Recruitment dynamics in complex life cycles. Science 241, 1460-1466.

Roughgarden J, Running SW and Matson PA (1991) What does remote sensing do for ecology? Ecology 72, 1918-1922.

Rugg DA and Norton TA (1986) Pelvelia canaliculata, a high-shore seaweed that shuns the sea. In Roberts RM (ed.) Plant Life in Aquatic and Amphibious Habitats, British Ecological Society Special Symposium, pp. 347-358.

Russell G (1972) Phytosociological studies on a two-zone shore: I. Basic pattern. The Journal of Ecology, 539-545.

Russell G (1973) Phytosociological Studies on a Two-Zone Shore: II. Community Structure. Journal of Ecology 61, 525-536.

Sanford E and Bertness M (2009) Latitudinal gradients in species interactions. In Witman, J and Kaustuv, R (eds) Marine macroecology, pp. 357.

Santini G, Thompson RC, Jenkins SR, Chelazzi G, Hartnoll RG, Kay SM and Hawkins SJ (2019) Barnacle cover modifies foraging behaviour of the intertidal limpet Patella vulgata. Journal of the Marine Biological Association of the United Kingdom 99, 17791786.

Scheffer M, Hosper SH, Meijer ML, Moss B and Jeppesen E (1993) Alternative equilibria in shallow lakes. Trends in Ecology \& Evolution 8, 275-279.

Schiel DR and Howard-Williams C (2016) Controlling inputs from the land to sea: Limitsetting, cumulative impacts and ki uta ki tai. Marine and Freshwater Research 67, 5764.

Schiel DR, Underwood AJ and Chapman MG (2019a) Biogeographic comparisons of pattern and process on intertidal rocky reefs of New Zealand and south-eastern Australia In Hawkins, SJ, Bohn, K, Firth, LB and Williams, GA (eds) Interactions in the marine benthos: Global patterns and processes. Cambridge University Press, pp. 391413.

Schiel DR, Alestra T, Gerrity S, Orchard S, Dunmore R, Pirker J, Lilley S, Tait L, Hickford $\mathbf{M}$ and Thomsen $\mathbf{M}(2019 b)$ The Kaikōura earthquake in southern New Zealand: Loss of connectivity of marine communities and the necessity of a cross-ecosystem perspective. Aquatic Conservation: Marine and Freshwater Ecosystems 29, 15201534.

Schonbeck M and Norton TA (1978) Factors controlling the upper limits of fucoid algae on the shore. Journal of Experimental Marine Biology and Ecology 31, 303-313.

Schonbeck M and Norton TA (1979a) An investigation of drought avoidance in intertidal fucoid algae. Botanica Marina 22, 133-144.

Schonbeck M and Norton TA (1979b) The effects of brief periodic submergence on intertodal fucoid algae. Estuarine and Coastal Marine Science 8, 205-211.

Schonbeck M and Norton TA (1979c) Drought-hardening in the upper-shore seaweeds Fucus spiralis and Pelvetia canaliculate 67, 687-696. 
Schonbeck M and Norton TA (1980a) Factors controlling the lower limits of fucoid algae on the shore. Journal of Experimental Marine Biology and Ecology 43, 131-150.

Schonbeck M and Norton TA (1980b) The effects on intertidal fucoid algae of exposure to air under various conditions. Botanica Marina 23, 141-148.

Seabra R, Wethey DS, Santos AM and Lima FP (2011) Side matters: Microhabitat influence on intertidal heat stress over a large geographical scale. Journal of Experimental Marine Biology and Ecology 400, 200-208.

Shanks AL (1983) Surface slicks associated with tidally forced internal waves may transport pelagic larvae of benthic invertebrates and fishes shoreward. Marine Ecology Progress Series 13, 311-315.

Shanks AL (1986) Tidal periodicity in the daily settlement of intertidal barnacle larvae and a hypothesized mechanism for the cross-shelf transport of cyprids. The Biological Bulletin 170, 429-440.

Shanks AL and Wright WG (1986) Adding teeth to wave action: the destructive effects of wave-borne rocks on intertidal organisms. Oecologia 69, 420-428.

Shima JS (2001) Regulation of local populations of a coral reef fish via joint effects of densityand number-dependent mortality. Oecologia 126, 58-65.

Shkedy $\mathbf{Y}$ and Roughgarden $\mathbf{J}$ (1997) Barnacle recruitment and population dynamics predicted from coastal upwelling. Oikos, 487-498.

Shumway SW and Bertness MD (1994) Patch size effects on marsh plant secondary succession mechanisms. Ecology 75, 564-568.

Silliman BR and Bertness MD (2002) A trophic cascade regulates salt marsh primary production. Proceedings of the National Academy of Sciences 99, 10500-10505.

Silliman BR, Bertness MD, Altieri AH, Griffin JN, Bazterrica MC, Hidalgo FJ, Crain CM and Reyna MV (2011) Whole-community facilitation regulates biodiversity on Patagonian rocky shores. PLoS One 6, e24502.

Silva ACF, Hawkins SJ, Boaventura DM and Thompson RC (2008) Predation by small mobile aquatic predators regulates populations of the intertidal limpet Patella vulgata (L.). Journal of Experimental Marine Biology and Ecology 367, 259-265.

Silva ACF, Hawkins S, Clarke K, Boaventura D and Thompson R (2010) Preferential feeding by the crab Necora puber on differing sizes of the intertidal limpet Patella vulgata. Marine Ecology Progress Series 416, 179-188.

Silva ACF, Boaventura DM, Thompson RC and Hawkins SJ (2014) Spatial and temporal patterns of subtidal and intertidal crabs excursions. Journal of Sea Research 85, 343348.

Silvertown J (2009) A new dawn for citizen science. Trends in Ecology \& Evolution 24, 467471.

Smith J (1968) Torrey Canyon pollution and marine life: a report by the Plymouth Laboratory of the Marine Biological Association of the United Kingdom, Cambridge: Cambridge University Press.

Solan M, Batty P, Bulling M and Godbold JA (2008) How biodiversity affects ecosystem processes: implications for ecological revolutions and benthic ecosystem function. Aquatic Biology 2, 289-301.

Solan M, Aspden RJ and Paterson DM (2012) Marine biodiversity and ecosystem functioning: frameworks, methodologies, and integration, Oxford University Press.

Sousa WP (1979a) Experimental investigations of disturbance and ecological succession in a rocky intertidal algal community. Ecological Monographs 49, 227-254.

Sousa WP (1979b) Disturbance in marine intertidal boulder fields: The nonequilibrium maintenance of species diversity. Ecology 60, 1225-1239.

Sousa WP (1984a) Intertidal mosaics: patch size, propagule availability, and spatially variable patterns of succession. Ecology 65, 1918-1935.

Sousa WP (1984b) The role of disturbance in natural communities. Annual Review of Ecology and Systematics 15, 353-391.

Southward AJ (1956) The population balance between limpets and seaweeds on wavebeaten rocky shores. Annual Report Marine Biological Station, Port Erin 68, 20-29. 
Southward AJ (1963) The distribution of some plankton animals in the English Channel and approaches: III. Theories about long-term biological changes, including fish. Journal of the Marine Biological Association of the United Kingdom 43, 1-29.

Southward AJ (1964) Limpet grazing and the control of vegetation on rocky shores, Oxford: Blackwell Scientific.

Southward AJ (1967) Recent changes in abundance of intertidal barnacles in south-west England: a possible effect of climatic deterioration. Journal of the Marine Biological Association of the United Kingdom 47, 81.

Southward AJ (1976) On the taxonomic status and distribution of Chthamalus stellatus (Cirripedia) in the north-east Atlantic region: with a key to the common intertidal barnacles of Britain. Journal of the Marine Biological Association of the United Kingdom 56, 1007-1028.

Southward AJ and Crisp DJ (1954) Recent changes in the distribution of the intertidal barnacles Chthamalus stellatus Poli and Balanus balanoides in the British Isles. Journal of Animal Ecology 23, 163-177.

Southward AJ and Orton JH (1954) The effects of wave-action on the distribution and numbers of the commoner plants and animals living on the Plymouth breakwater. Journal of the Marine Biological Association of the United Kingdom 33, 1.

Southward AJ and Southward EC (1978) Recolonization of rocky shores in Cornwall after use of toxic dispersants to clean up the Torrey Canyon spill. Journal of the Fisheries Research Board of Canada 35, 682-706.

Southward AJ, Hawkins SJ and Burrows MT (1995) Seventy years' observations of changes in distribution and abundance of zooplankton and intertidal organisms in the western English Channel in relation to rising sea temperature. Journal of Thermal Biology 20, 127-155.

Stachowicz JJ (2001) Mutualism, facilitation, and the structure of ecological communities: positive interactions play a critical, but underappreciated, role in ecological communities by reducing physical or biotic stresses in existing habitats and by creating new habitats on which many species depend. Bioscience 51, 235-246.

Steneck RS and Dethier MN (1994) A functional group approach to the structure of algaldominated communities. Oikos, 476-498.

Steneck RS, Graham MH, Bourque BJ, Corbett D, Erlandson JM, Estes JA and Tegner MJ (2003) Kelp forest ecosystems: biodiversity, stability, resilience and future. Environmental Conservation 29, 436-459.

Stephenson TA and Stephenson A (1949) The universal features of zonation between tidemarks on rocky coasts. The Journal of Ecology 37, 289.

Stephenson TA and Stephenson A (1972) Life between tidemarks on rocky shores, New York: W. H. Freeman \& Co Ltd.

Strathmann R, Branscomb E and Vedder K (1981) Fatal errors in set as a cost of dispersal and the influence of intertidal flora on set of barnacles. Oecologia 48, 13-18.

Sugden HE, Underwood A and Hawkins SJ (2009) The aesthetic value of littoral hard substrata and consideration of ethical frameworks for their investigation and conservation. In Wahl, M (ed.) Marine hard bottom communities. Berlin: Springer, pp. 409-422.

Sutherland JP (1990) Recruitment regulates demographic variation in a tropical intertidal barnacle. Ecology 71, 955-972.

Svensson CJ, Jenkins SR, Hawkins SJ and Åberg P (2005) Population resistance to climate change: modelling the effects of low recruitment in open populations. Oecologia 142, 117-126.

Taylor DI and Schiel DR (2010) Algal populations controlled by fish herbivory across a wave exposure gradient on southern temperate shores. Ecology 91, 201-211.

Thompson RC, Norton TA and Hawkins SJ (1998) The influence of epilithic microbial films on the settlement of Semibalanus balanoides cyprids - a comparison between laboratory and field experiments. Hydrobiologia 375, 203-216. 
Thompson RC, Tobin M, Hawkins SJ and Norton T (1999) Problems in extraction and spectrophotometric determination of chlorophyll from epilithic microbial biofilms: towards a standard method. Journal of the Marine Biological Association of the United Kingdom 79, 551-558.

Thompson RC, Crowe T and Hawkins SJ (2002) Rocky intertidal communities: past environmental changes, present status and predictions for the next 25 years. Environmental Conservation 29, 168-191.

Thompson RC, Norton TA and Hawkins SJ (2004) Physical stress and biological regulation control pattern and process in benthic biofilms. Ecology 85, 1372-1382.

Todd CD and Keough MJ (1994) Larval settlement in hard substratum epifaunal assemblages: a manipulative field study of the effects of substratum filming and the presence of incumbents. Journal of Experimental Marine Biology and Ecology 181, 159-187.

Townhill B and Hyder K (2017) Citizen science and marine policy. In Cigliano, JA and Ballard, HL (eds) Citizen science for coastal and marine conservation. Routledge, pp. 178-194.

Underwood AJ (1978) An experimental evaluation of competition between three species of intertidal prosobranch gastropods. Oecologia 33, 185-202.

Underwood AJ (1980) The effects of grazing by gastropods and physical factors on the upper limits of distribution of intertidal macroalgae. Oecologia 46, 201-213.

Underwood AJ (1981) Techniques of analysis of variance in experimental marine biology and ecology. Oceanography and Marine Biology: An Annual Review 19, 513-605.

Underwood AJ (1984) Vertical and seasonal patterns in competition for microalgae between intertidal gastropods. Oecologia 64, 211-222.

Underwood AJ (1986) The analysis of competition by Weld experiments. In Kikkawa J and Anderson DJ (eds) Community ecology: Pattern and process. London: Blackwell, pp. 240-268.

Underwood AJ (1988) Design and analysis of field experiments on competitive interactions affecting behaviour of intertidal animals. In Chelazzi, $G$ and Vannini $M$ (eds) Behavourial adaptations for life in intertidal habitats. Boston: Springer, pp. 333-357.

Underwood AJ (1991a) The logic of ecological experiments: a case history from studies of the distribution of macro-algae on rocky intertidal shores. Journal of the Marine Biological Association of the United Kingdom 71, 841-866.

Underwood AJ (1991b) Beyond BACl: experimental designs for detecting human environmental impacts on temporal variations in natural populations. Marine and Freshwater Research 42, 569-587.

Underwood AJ (1992a) Competition and marine plant-animal interactions. In John, DM, Hawkins, SJ and Price, JH (eds) Plant-animal interactions in the marine benthos. Oxford: Clarendon, pp. 443-475.

Underwood AJ (1992b) Beyond BACl: the detection of environmental impacts on populations in the real, but variable, world. Journal of Experimental Marine Biology and Ecology 161, 145-178.

Underwood AJ (1994) On beyond BACl: sampling designs that might reliably detect environmental disturbances. Ecological Applications 4, 3-15.

Underwood AJ (1997) Experiments in ecology: their logical design and interpretation using analysis of variance, Cambridge university press.

Underwood AJ (1998) Grazing and disturbance: an experimental analysis of patchiness in recovery from a severe storm by the intertidal alga Hormosira banksii on rocky shores in New South Wales. Journal of Experimental Marine Biology and Ecology 231, 291306.

Underwood AJ and Jernakoff P (1981) Effects of interactions between algae and grazing gastropods on the structure of a low-shore intertidal algal community. Oecologia 48, 221-233.

Underwood AJ and Denley EJ (1984) Paradigms, Explanations, and Generalizations in Models for the Structure of Intertidal Communities on Rocky Shores. In Strong, DR, 
Simberloff, D, Abele, LG and Thistle, AB (eds) Ecological communities. Princeton: Princeton University Press.

Underwood AJ and Jernakoff P (1984) The effects of tidal height, wave-exposure, seasonality and rock-pools on grazing and the distribution of intertidal macroalgae in New South Wales. Journal of Experimental Marine Biology and Ecology 75, 71-96.

Underwood AJ and Chapman MG (1985) Multifactorial analyses of directions of movement of animals. Journal of Experimental Marine Biology and Ecology 91, 17-43.

Underwood AJ and Fairweather PG (1989) Supply-side ecology and benthic marine assemblages. Trends in Ecology \& Evolution 4, 16-20.

Underwood AJ and Chapman M (1992) Published. Experiments on topographic influences on density and dispersion of Littorina unifasciata in New South Wales. Proceedings of the Third International Symposium on Littorinid Biology. The Malacological Society of London. pp. 181-195.

Underwood AJ, Denley E and Moran M (1983) Experimental analyses of the structure and dynamics of mid-shore rocky intertidal communities in New South Wales. Oecologia 56, $202-219$.

Underwood AJ, Chapman M and Connell S (2000) Observations in ecology: you can't make progress on processes without understanding the patterns. Journal of Experimental Marine Biology and Ecology 250, 97-115.

Vadas R, Wright WA and Miller SL (1990) Recruitment of Ascophyllum nodosum: wave action as a source of mortality. Marine Ecology Progress Series 61, 263.

Vadas RS, Burrows M and Hughes R (1994) Foraging strategies of dogwhelks, Nucella lapillus (L.): Interacting effects of age, diet and chemical cues to the threat of predation. Oecologia 100, 439-450.

Vaselli S, Bertocci I, Maggi E and Benedetti-Cecchi L (2008) Effects of mean intensity and temporal variance of sediment scouring events on assemblages of rocky shores. Marine Ecology Progress Series 364, 57-66.

Velimirov B and Griffiths CL (1979) Wave-induced kelp movement and its importance for community structure. Botanica Marina 22, 169-72.

Vye SR, Emmerson MC, Arenas F, Dick JT and O'Connor NE (2015) Stressor intensity determines antagonistic interactions between species invasion and multiple stressor effects on ecosystem functioning. Oikos 124, 1005-1012.

Vye SR, Dickens S, Adams L, Bohn K, Chenery J, Dobson N, Dunn RE, Earp HS, Evans M, Foster C, Grist H, Holt B, Hull S, Jenkins SR, Lamont P, Long S, Mieszkowska $\mathrm{N}$, Millard J, Morrall Z, Pack K, Parry-Wilson H, Pocklington J, Pottas J, Richardson L, Scott A, Sugden H, Watson G, West V, Winton D, Delany $\mathbf{J}$ and Burrows MT (2020) Patterns of abundance across geographical ranges as a predictor for responses to climate change: Evidence from UK rocky shores. Diversity and Distributions 26, 1357-1365.

Wahl M (1989) Marine epibiosis. I. Fouling and antifouling: some basic aspects. Marine Ecology Progress Series 58, 175-189.

White L, Donohue I, Emmerson MC and O'Connor NE (2018) Combined effects of warming and nutrients on marine communities are moderated by predators and vary across functional groups. Global Change Biology 24, 5853-5866.

Wieczorek SK, Clare AS and Todd CD (1995) Inhibitory and facilitatory effects of microbial films on settlement of Balanus amphitrite amphitrite larvae. Oceanographic Literature Review 11, 999.

Wieters EA, Kaplan D, Navarrete S, Sotomayor A, Largier J, Nielsen KJ and Veliz F (2003) Alongshore and temporal variability in chlorophyll a concentration in Chilean nearshore waters. Marine Ecology Progress Series 249, 93-105.

Wieters EA (2005) Upwelling control of positive interactions over mesoscales: a new link between bottom-up and top-down processes on rocky shores. Marine Ecology Progress Series 301, 43-54. 
Williams AE, Moss B and Eaton J (2002) Fish induced macrophyte loss in shallow lakes: top-down and bottom-up processes in mesocosm experiments. Freshwater Biology 47, 2216-2232.

Williams GA, Chan BKK and Dong Y-W (2019) Rocky shores of mainland China, Taiwan and Hong Kong: Pact present and future. In Hawkins, SJ, Bohn, K, Firth, LB and Williams, GA (eds) Interactions in the marine benthos: Global patterns and processes. Cambridge University Press, pp. 360-390.

Wilson J and Osenberg CW (2002) Experimental and observational patterns of densitydependent settlement and survival in the marine fish Gobiosoma. Oecologia 130, 205215.

Wolcott TG (1973) Physiological ecology and intertidal zonation in limpets (Acmaea): A critical look at "limiting factors". The Biological Bulletin 145, 389-422.

Woodward G (2009) Biodiversity, ecosystem functioning and food webs in fresh waters: assembling the jigsaw puzzle. Freshwater Biology 54, 2171-2187.

Wright J, Williams S and Dethier M (2004) No zone is always greener: variation in the performance of Fucus gardneri embryos, juveniles and adults across tidal zone and season. Marine Biology 145, 1061-1073.

Xavier BM, Branch GM and Wieters E (2007) Abundance, growth and recruitment of Mytilus galloprovincialis on the west coast of South Africa in relation to upwelling. Marine Ecology Progress Series 346, 189-201.

Yesson C, Bush LE, Davies AJ, Maggs CA and Brodie J (2015) Large brown seaweeds of the British Isles: evidence of changes in abundance over four decades. Estuarine, Coastal and Shelf Science 155, 167-175.

Zardi GI, Nicastro KR, Canovas F, Ferreira Costa J, Serrão EA and Pearson GA (2011) Adaptive traits are maintained on steep selective gradients despite gene flow and hybridization in the intertidal zone. PLOS ONE 6, e19402.

Zhang YS and Silliman BR (2019) A facilitation cascade enhances local biodiversity in seagrass beds. Diversity 11, 30. 